OPEN ACCESS

Edited by:

Genlou Sun,

Saint Mary's University, Canada

Reviewed by:

Jun Zhang,

Jilin Agriculture University, China

Xiaohong Yang,

China Agricultural University, China

*Correspondence:

Wen-Xia L

liwenxianeau@126.com

Hailong Ning

ninghailongneau@126.com

tThese authors have contributed equally to this work

Specialty section:

This article was submitted to Evolutionary and Population Genetics,

a section of the journal

Frontiers in Genetics

Received: 10 January 2020

Accepted: 11 May 2020

Published: 25 June 2020

Citation:

Tian X, Zhang K, Liu S, Sun X, Li X,

Song J, Qi Z, Wang Y, Fang $Y$,

Wang J, Jiang S, Yang C, Tian Z,

Li W-X and Ning H (2020) Quantitative Trait Locus Analysis of Protein and Oil

Content in Response to Planting Density in Soybean (Glycine max [L.] Merri.) Seeds Based on SNP Linkage

Mapping. Front. Genet. 11:563.

doi: 10.3389/fgene.2020.00563

\section{Quantitative Trait Locus Analysis of Protein and Oil Content in Response to Planting Density in Soybean (Glycine max [L.] Merri.) Seeds Based on SNP Linkage Mapping}

\author{
Xiaocui Tian ${ }^{1,2,3+}$, Kaixin Zhang ${ }^{1,2,3+}$, Shulin Liu ${ }^{4}$, Xu Sun ${ }^{1,2,3}$, Xiyu Li ${ }^{1,2,3}$, Jie Song ${ }^{1,2,3}$, \\ Zhongying Qi ${ }^{1,2,3}$, Yue Wang ${ }^{1,2,3}$, Yanlong Fang 1,2,3, Jiajing Wang ${ }^{1,2,3}$, Sitong Jiang 1,2,3, \\ Chang Yang ${ }^{1,2,3}$, Zhixi Tian ${ }^{4}$, Wen-Xia $\mathrm{Li}^{1,2,3^{*}}$ and Hailong Ning ${ }^{1,2,3 *}$ \\ ${ }^{1}$ Key Laboratory of Soybean Biology, Ministry of Education, Northeast Agricultural University, Harbin, China, ${ }^{2}$ Key Laboratory \\ of Soybean Biology and Breeding/Genetics, Ministry of Agriculture, Northeast Agricultural University, Harbin, China, \\ ${ }^{3}$ Soybean Research Institute, Northeast Agricultural University, Harbin, China, ${ }^{4}$ State Key Laboratory of Plant Cell and \\ Chromosome Engineering, Institute of Genetics and Developmental Biology, Chinese Academy of Sciences, Beijing, China
}

Soybean varieties suitable for high planting density allow greater yields. However, the seed protein and oil contents, which determine the value of this crop, can be influenced by planting density. Thus, it is important to understand the genetic basis of the responses of different soybean genotypes to planting density. In this study, we quantified the protein and oil contents in a four-way recombinant inbred line (FW-RIL) soybean population under two planting densities and the response to density. We performed quantitative trait locus (QTL) mapping using a single nucleotide polymorphism (SNP) linkage map generated by inclusive composite interval mapping. We identified 14 QTLs for protein content and 17 for oil content at a planting density of $2.15 \times 10^{5}$ plant/ha (D1) and 14 QTLs for protein content and 20 for oil content at a planting density $3.0 \times 10^{5}$ plant/ha (D2). Among the QTLs detected, two oil-content QTLs was detected at both plant densities. In addition, we identified 38 QTLs for the responses of protein and oil contents to planting density. Of the QTLs detected, 70 were identified in previous studies, while 33 were newly identified. Fourty-five QTLs accounted for over 10\% of the phenotypic variation of the corresponding trait, based on 23 QTLs at a marker interval distance of $\sim 600 \mathrm{~kb}$ detected under different densities and with the responses to density difference. Pathway analysis revealed four candidate genes involved in protein and oil biosynthesis/metabolism. These results improve our understanding of the genetic underpinnings of protein and oil biosynthesis in soybean, laying the foundation for enhancing protein and oil contents and increasing yields in soybean.

Keywords: soybean, protein and oil content, density, gene, density response 


\section{INTRODUCTION}

Soybean (Glycine max [L.] Merri.) is a major source of vegetable oil and feed protein. Dry soybean seeds are composed of approximately $40 \%$ protein and $20 \%$ oil (Rajcan et al., 2005). Increasing the protein content (PC) and oil content (OC) of soybean seeds is an important breeding objective.

The protein and oil contents of seeds are inherited as quantitative traits controlled by multiple genes, leading to a low efficiency of soybean improvement based on phenotypic selection. Therefore, much research has focused on quantitative trait locus (QTL) mapping for protein and oil content. To date, 248 QTLs for protein content and 327 for oil content have been deposited in SoyBase (http://www.soybase.org). Most of this research was carried out using conventional molecular marker techniques (Powell et al., 1996), such as restriction fragment length polymorphism (RFLP), amplified fragment length polymorphism (AFLP), and simple sequence repeat (SSR) mapping, which has reduced the accuracy of QTL mapping and led to reduced genetic stability due to the low densities of these markers and their uneven distributions in the genome. In recent years, single nucleotide polymorphism (SNP) markers have become powerful tools for exploring plant genomes due to their high density, good genetic stability, and suitability for accurate, high-throughput genotyping (Lee et al., 2015; Zhang et al., 2018). SNPs markers have been successfully used in soybean research. For example, Liu et al. (2017) used parental Zhong huang $\times$ Hua xia3 hybridization RIL populations obtained using SNP markers and detected four QTLs for protein content and nine QTLs for oil content in two environments in 2 years. Akond et al. (2014) detected one QTL for protein content and 11 QTLs for oil content using an $\mathrm{F}_{5}$ : 8 RIL population derived from MD 96-5722 $\times$ Spencer using 5376 SNP markers. Wang et al. (2015) used an RIL population from V97-1346 × R05-4256 and detected 13 SNPs for protein content. In these studies, QTL mapping for protein and oil content in soybean plants was conducted using bi-parental populations. This technique has several limitations, as it results in the detection a small number of QTLs and limits the richness of the alleles and phenotypic variation. However, more recently, four-way recombinant inbred line (FW-RIL) populations have been used for QTL mapping, which overcomes the limitation posed by populations with a narrow genetic basis. In addition, these lines contain four alleles in a single locus, which greatly improves the QTL detection capacity. Moreover, high-density linkage maps can be constructed using FW-RIL populations, and the genetic markers are highly polymorphic (Ning et al., 2016; Liu et al., 2019).

In recent decades, the planting density of soybean has gradually been increasing, which has greatly affected the quality of soybean seeds. Bellaloui et al. (2014) investigated the effects of planting density on the composition of soybean seeds and observed that the highest protein and the highest oil contents occurred at different planting densities. Akond et al. (2012) detected two QTLs for protein and 6 QTLs for oil content at a higher planting density $(25 \mathrm{~cm}$ row spacing) and three QTLs for oil content at a lower plant density $(50 \mathrm{~cm}$ row spacing). By comparing the phenotypes and QTLs detected, many different genetic bases for protein and oil content at different planting densities have been uncovered. It is therefore important to breed plant varieties that are suitable for various planting densities and to analyze the genetic basis of the effects of planting densities on protein and oil content.

In the current study, we analyzed the genetic basis of the responses of protein and oil contents in soybean to different planting densities based on phenotypic data from a 144 member FW-RIL population and high-density SNP maps. We identified 45 QTLs with phenotypic variance explained (PVE) values of $>10 \%$ under different planting densities and with the responses to density difference. Finally, we identified four candidate genes that might control protein and oil content under the influence of planting density that could be useful to improve molecular breeding and increase the protein and oil contents of soybean.

\section{MATERIALS AND METHODS}

\section{Plant Materials}

Four soybean varieties, Kenfeng 14 (protein content $39.69 \%$ and oil content 20.34\%), Kenfeng 15 (protein content $38.68 \%$ and oil content $22.76 \%$ ), Heinong 48 (protein content $44.74 \%$ and oil content $19.05 \%$ ), and Kenfeng 19 (protein content $42.52 \%$ and oil content $19.26 \%$ ), were used as parents to construct an FW-RIL population. Kenfeng 14, Kenfeng 15, Heinong 48, and Kenfeng 19 were obtained by crossing Suinong $10 \times$ Changnong 5 , Suinong $14 \times$ Kenjiao 9307, Hefeng $25 \times$ (Kenfeng $4 \times$ Gong 8861-0), and Ha 90-6719 × Sui 90-5888, respectively (Table S1). Two $F_{1}$ seeds were harvested by crossing Kenfeng $14 \times$ Kenfeng 15 and Heinong $48 \times$ Kenfeng 19 in 2008 . The FW-F1 populations were obtained by crossing plants from two F1 seeds in 2009. From 2010 to 2012, FW-F1 seeds were planted in Harbin, China in the summer and in Hainan in the winter. The plants were self-crossed for six generations to obtain a stable FW-RIL population using the single-seed descent method. The 144 resulting FW-RILs were used in the experiments.

\section{Field Experiment and Trait Measurements}

The entire experiment was conducted in 2015 and 2016. In 2015, the test sites were Harbin $\left(45^{\circ} 43^{\prime} \mathrm{N}, 126^{\circ} 45^{\prime} \mathrm{E}\right)$ (E1) and Keshan $\left(48^{\circ} 18^{\prime} \mathrm{N}, 126^{\circ} 15^{\prime} \mathrm{E}\right)(\mathrm{E} 2)$; in 2016 , the test sites were Acheng $\left(45^{\circ} 32^{\prime} \mathrm{N}, 126^{\circ} 58^{\prime} \mathrm{E}\right)(\mathrm{E} 3)$, Shuangcheng $\left(45^{\circ} 22^{\prime} \mathrm{N}, 126^{\circ} 18^{\prime} \mathrm{E}\right)$ (E4), and Harbin (E5). The field experiments were arranged in a split-plot design with three replications. The main treatment comprised a normal planting density of $2.15 \times 10^{5}$ plants/ha (D1) and an increased planting density of $3.0 \times 10^{5}$ plants/ha (D2), which were implemented using a plant spacing of 0.07 and $0.05 \mathrm{~m}$, respectively, in each row of a three-ridge block 3 meters long and 2.1 meters wide. The four parents and FWRILs were planted in a subplot with a random permutation. The environmental conditions, fertility, year, planting date, planting location, annual rainfall, and annual accumulated temperature are summarized in Table S2. Field management was performed using local field cultivation conditions for soybean.

Five mature plants obtained from the four parental lines and the FW-RIL population were randomly selected from the middle row of each plot. Protein and oil content were measured using 

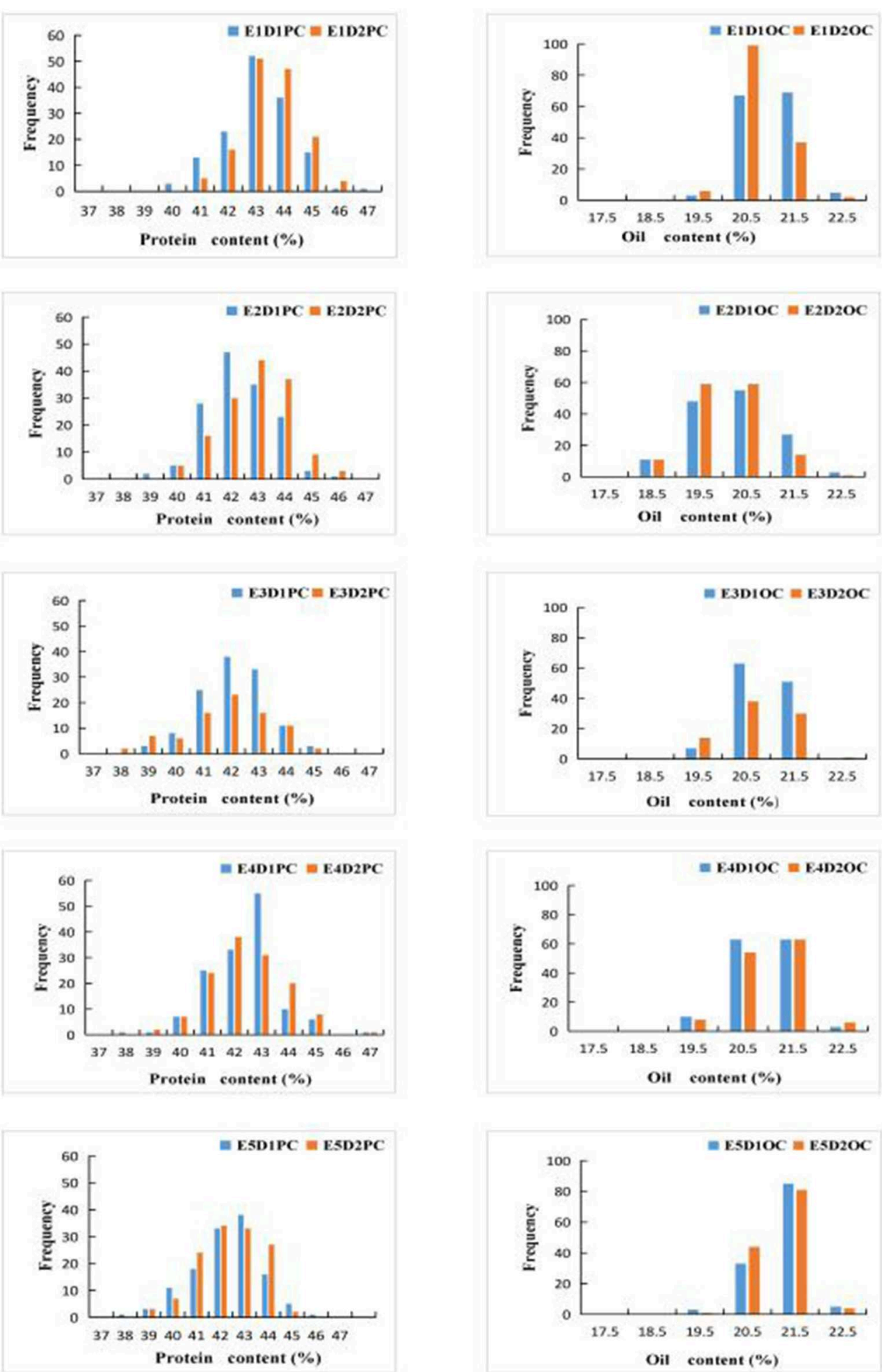

FIGURE 1 | Bar charts of protein content (PC) and oil content (OC) values in the FW-RIL population. E1: Harbin (2015), E2: Keshan (2015), E3: Acheng (2016), E4: Shuangcheng (2016), E5: Harbin (2016), D1: the first (lower) planting density $\left(2.15 \times 10^{5}\right.$ plants/ha), D2: the second (higher) planting density (3 $\times 10^{5}$ plants/ha). 
an INFRAC TM1214 near-infrared grain quality analyzer (Foss). The detailed process is described in Zhang et al. (2018). The average values of three samples were used as the phenotypic values of the parents and FW-RILs.

\section{Statistical Analysis}

\section{Estimating the Effect of Density}

The response to density (RD) value refers to the change in the quality of a trait due to an increase in the planting density. $\mathrm{RD}$ was calculated as the remainder of the trait value at high density (D2) after subtracting the trait value at normal density (D1). Specifically, RD was estimated using the conditional variable method (Zhu, 1995) with the following formula:

$$
R D=y_{D 2}-C_{D 1 D 2}\left(y_{D 1}-\bar{y}_{D 1}\right) / V_{D 1}
$$

where $R D$ is the response to density difference, $y_{D 1}$ is the phenotypic value of the first (normal) density, $y_{D 2}$ is the phenotype value of the second (high) density, $C_{D 1 D 2}$ is the covariance between phenotypes of quality traits under the two densities, and $\bar{y}_{D 1}$ and $V_{D 1}$ are the average and variance, respectively, of quality traits under the first (normal) density.

The maximum, minimum, standard deviation, range, skewness, and kurtosis of the protein and oil content for each density in each environment were also calculated. Analysis of variance (ANOVA) was conducted to compare the phenotypic values of protein and oil contents at each planting density in each environment or jointly in multiple environments and in response to density difference.

Similar to the method used to estimate average heritability in multiple macro-environments, the average broad-sense heritability $\left(h^{2}\right)$ at multiple planting densities was estimated using the following equation:

$$
h^{2}=\frac{\sigma_{G}^{2}}{\sigma_{G}^{2}+\frac{\sigma_{G D}^{2}}{d}+\frac{\sigma^{2}}{e r d}}
$$

where $h^{2}$ is broad-sense heritability, $\sigma_{G}^{2}$ is the variance of the genotype, $\sigma_{G D}^{2}$ is the genotype $\times$ density interaction, $\sigma^{2}$ is the variance of error, $e$ is the number of environments, $d$ is the number of planting densities, and $r$ is the number of replications. The data for protein and oil content were analyzed using Proc MIXED in SAS 9.2 statistical software (SAS Institute, Cary, NC, US).

\section{SNP Genotyping}

DNA was extracted from the fresh leaves of plants from the FW-RIL population from the cross (Kenfeng $14 \times$ Kenfeng 15) $\times$ (Heinong $48 \times$ Kenfeng 19) using the CTAB method (Doyle and Doyle, 1990). The DNA was used for SNP genotyping analysis with the SoySNP660K BeadChip at Beijing Boao Biotechnology Co., Ltd. The SNP markers were filtered for minor allele frequency (MAF > 0.05), with a maximum of $<10 \%$ missing sites per SNP (Belamkar et al., 2016). A linkage map of soybean containing 2332 SNP markers (https://figshare.

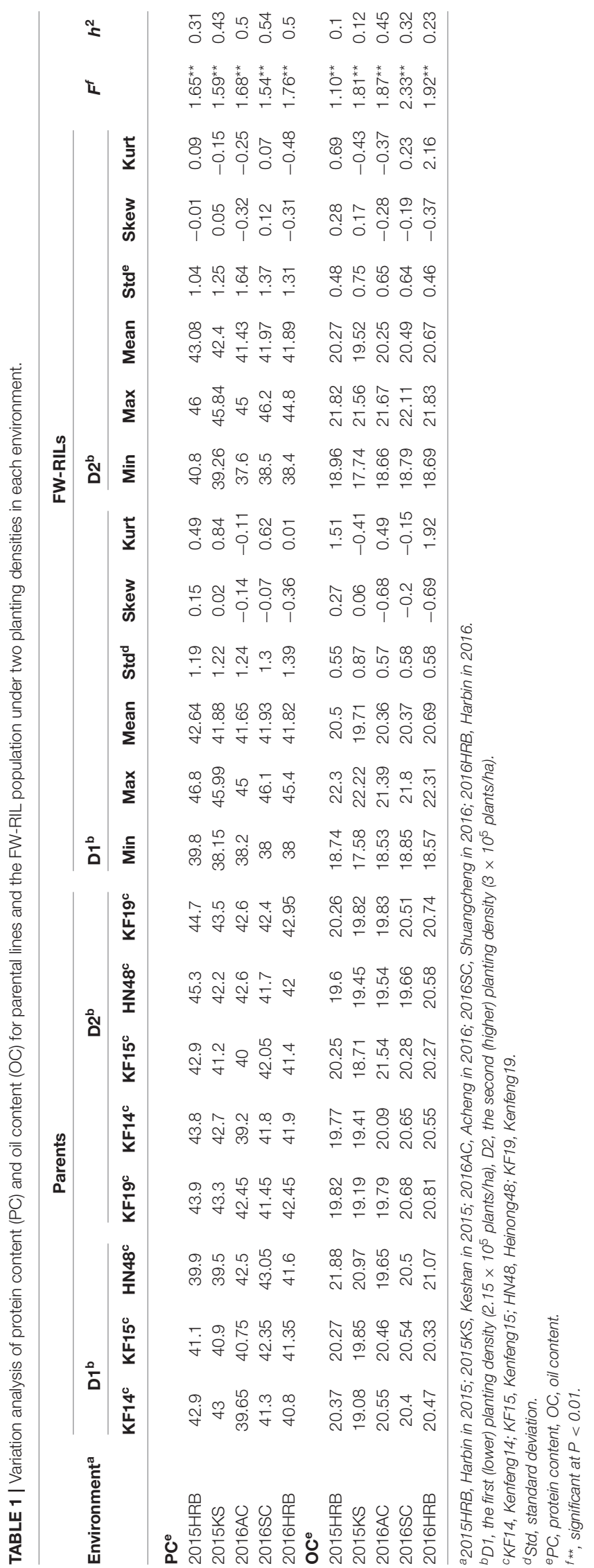


TABLE 2 | Joint ANOVA for protein content (PC) and oil content (OC) for the FW-RIL population across five environments.

\begin{tabular}{|c|c|c|c|c|c|c|c|c|c|c|c|}
\hline \multirow[t]{2}{*}{ Source } & \multirow[t]{2}{*}{ DF } & \multicolumn{4}{|c|}{ PC } & \multirow[b]{2}{*}{ Variance component } & \multicolumn{4}{|c|}{ OC } & \multirow[b]{2}{*}{ Variance component } \\
\hline & & SS & MS & $\mathbf{F}$ & $\operatorname{Pr}>F$ & & SS & MS & $\mathbf{F}$ & $\mathbf{P r}>\mathbf{F}$ & \\
\hline Environment (E) & 4 & 680.30 & 170.08 & 45.01 & $<0.0001$ & 0 & 520.66 & 130.17 & 123.99 & $<0.0001$ & 0 \\
\hline Planting density (D) & 1 & 19.08 & 19.08 & 5.05 & 0.0247 & 0.0048 & 2.53 & 2.53 & 2.41 & 0.1208 & 0.002 \\
\hline Genotype (G) & 143 & 2,095.62 & 14.65 & 3.88 & $<0.0001$ & 0.34 & 363.47 & 2.54 & 2.42 & $<0.0001$ & 0.045 \\
\hline$G \times D$ & 143 & 900.74 & 6.30 & 1.67 & $<0.0001$ & 0.17 & 222.15 & 1.55 & 1.48 & 0.0003 & 0.033 \\
\hline$E \times D$ & 4 & 70.51 & 17.63 & 4.67 & 0.0009 & 0.038 & 18.14 & 4.54 & 4.32 & 0.0017 & 0.007 \\
\hline Error & 2602 & $9,831.03$ & 3.78 & & & 3.66 & $2,731.57$ & 1.05 & & & 1.02 \\
\hline$h^{2}$ & & & & & & 0.62 & & & & & 0.47 \\
\hline
\end{tabular}

TABLE 3 | Variation analysis of protein content (PC) and oil content (OC) in the FW-RIL population in response to planting density.

\begin{tabular}{|c|c|c|c|c|c|c|c|c|c|}
\hline \multirow[t]{2}{*}{ Source } & \multirow[t]{2}{*}{ DF } & \multicolumn{4}{|c|}{ PC } & \multicolumn{4}{|c|}{ OC } \\
\hline & & SS & MS & $\mathbf{F}$ & $\operatorname{Pr}>\mathbf{F}$ & SS & MS & $\mathbf{F}$ & $\operatorname{Pr}>\mathrm{F}$ \\
\hline Replication & 2 & 66.50 & 6.65 & 1.55 & 0.12 & 17.61 & 1.76 & 1.66 & 0.09 \\
\hline Environment (E) & 4 & 263.47 & 65.87 & 15.36 & $<0.0001$ & 166.28 & 41.57 & 39.14 & $<0.0001$ \\
\hline Genotype (G) & 143 & 779.69 & 5.45 & 1.27 & 0.02 & 190.33 & 1.33 & 1.25 & 0.03 \\
\hline$E \times G$ & 562 & 2380.55 & 4.24 & 0.99 & 0.56 & 660.99 & 1.18 & 1.11 & 0.09 \\
\hline Error & 966 & 4141.34 & 4.29 & & & 1025.97 & 1.06 & & \\
\hline
\end{tabular}

com/s/4a7b8caea2c29f891bc3) was constructed using GAPL 1.2 software (http://www.isbreeding.net/software/), the length range covered is $3539.66 \mathrm{cM}$ on the soybean genome.

\section{QTL Analysis}

Based on the SNP linkage map, the average protein and oil contents under each planting density and RD in every environment were used to map the QTLs with the inclusive composite interval mapping (ICIM) method (Zhang S. et al., 2017) using GAPL V1.2. Firstly, The LOD (likelihood of odds) score for putative QTLs was determined after 1,000 permutations at a significant level of $P<0.05$ with objective to find major QTL. Then mapping QTL was re-analyzed by setting LOD score of 3 to screen minor QTL. The QTLs were named as follows: $\mathrm{q}$-trait name-chromosome name-sequence number, where $\mathrm{q}$ represents QTL, PC, and OC represent protein content and oil content, respectively, and $\mathrm{RD}$ represents the response to density. The QTLs that were mapped to the same marker region were given the same sequence number.

\section{Identification of Candidate Genes for Protein and Oil Content}

Twelve QTLs and eleven QTLs with PVE > 10\% were detected within a $600 \mathrm{~kb}$ genomic region under different planting densities and with the responses to density difference, respectively. To further explore whether these QTLs are related to protein and oil content in soybean, we attempted to identify the candidate genes associated with the QTLs. We used the Glyma.Wm82.a2.v1 gene model in SoyBase (https://soybase.org/SequenceIntro. php) to identify all gene sequences based on the intervals of each QTLs with PVE $>10 \%$. As a result, various highly expressed genes that controlled protein and oil content were identified based on the BAR website (http://www.bar.utoronto.ca). Finally, we used the KEGG website (http://www.kegg.jp/blastkoala/) to identify candidate protein and oil content-related genes based on KEGG pathway analysis results.

\section{RESULTS}

\section{Phenotypic Variation}

We constructed bar chats of the protein and oil contents of 144 FW-RILs (Figure 1). Protein and oil contents at different planting densities in the same environment exhibited a continuous normal distribution. Analysis of the protein and oil contents of the four parents at different densities located in the interval between the minimum and maximum values of the FW-RIL population (Table 1) indicated that the protein and oil contents of the FW-RILs was significantly higher than those of the parents, suggesting that transgressive inheritance was involved in protein and oil contents in the FW-RILs. Most of the kurtosis and skewness values of the data were between -1 and 1 , suggesting that the population was suitable for ANOVA of related traits. An $\mathrm{F}$ test revealed significant $(P$ $<0.01$ ) differences in quality traits among the densities in a single environment. Therefore, the FW-RILs were constructed from two high-oil (Kenfeng14, Kenfeng15) and two high-protein varieties (Kenfeng19, Heinong48), providing an ideal basis for QTL analysis.

ANOVA of the values of the parents and FW-RILs indicated that the genotype and genotype $x$ density interaction effect was significant $(P \leq 0.01$; Table 2$)$. Compared to direct density effects, the genotype $\times$ density interaction effect was significant, 

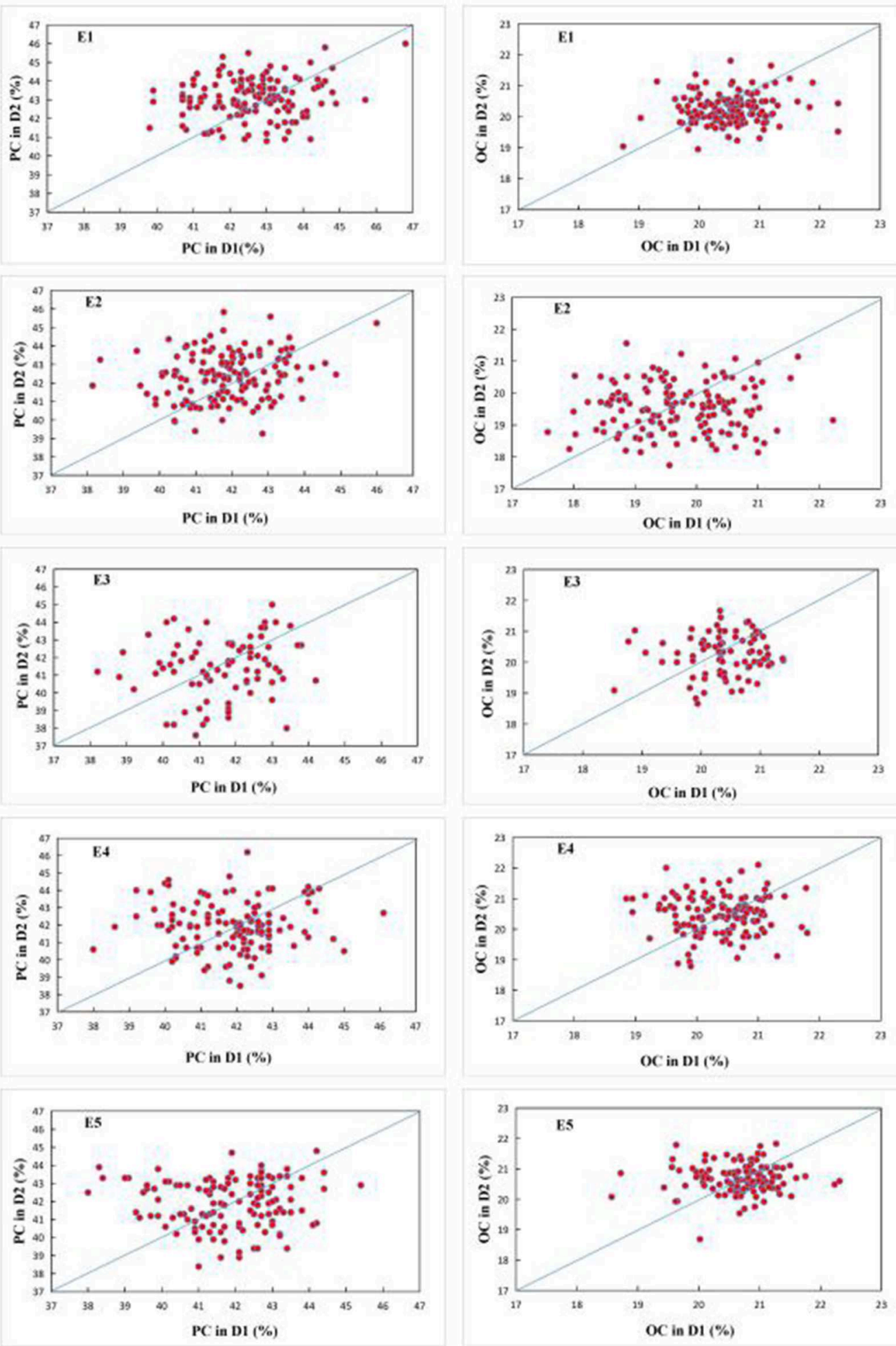

FIGURE 2 | Q-Q plot of seed protein (left) and oil (right) content under two planting densities across five environments. Each circle represents one FW-RIL. E1: Harbin (2015), E2: Keshan (2015), E3: Acheng (2016), E4: Shuangcheng (2016), E5: Harbin (2016).

indicating that density affects protein and oil content indirectly by altering the genetic basis of quality formation and that different genotypes have different responses to density increase.
The estimated broad-based heritability varied for protein and oil content at different planting densities in each environment, indicating that density influences the genetic basis of protein and 


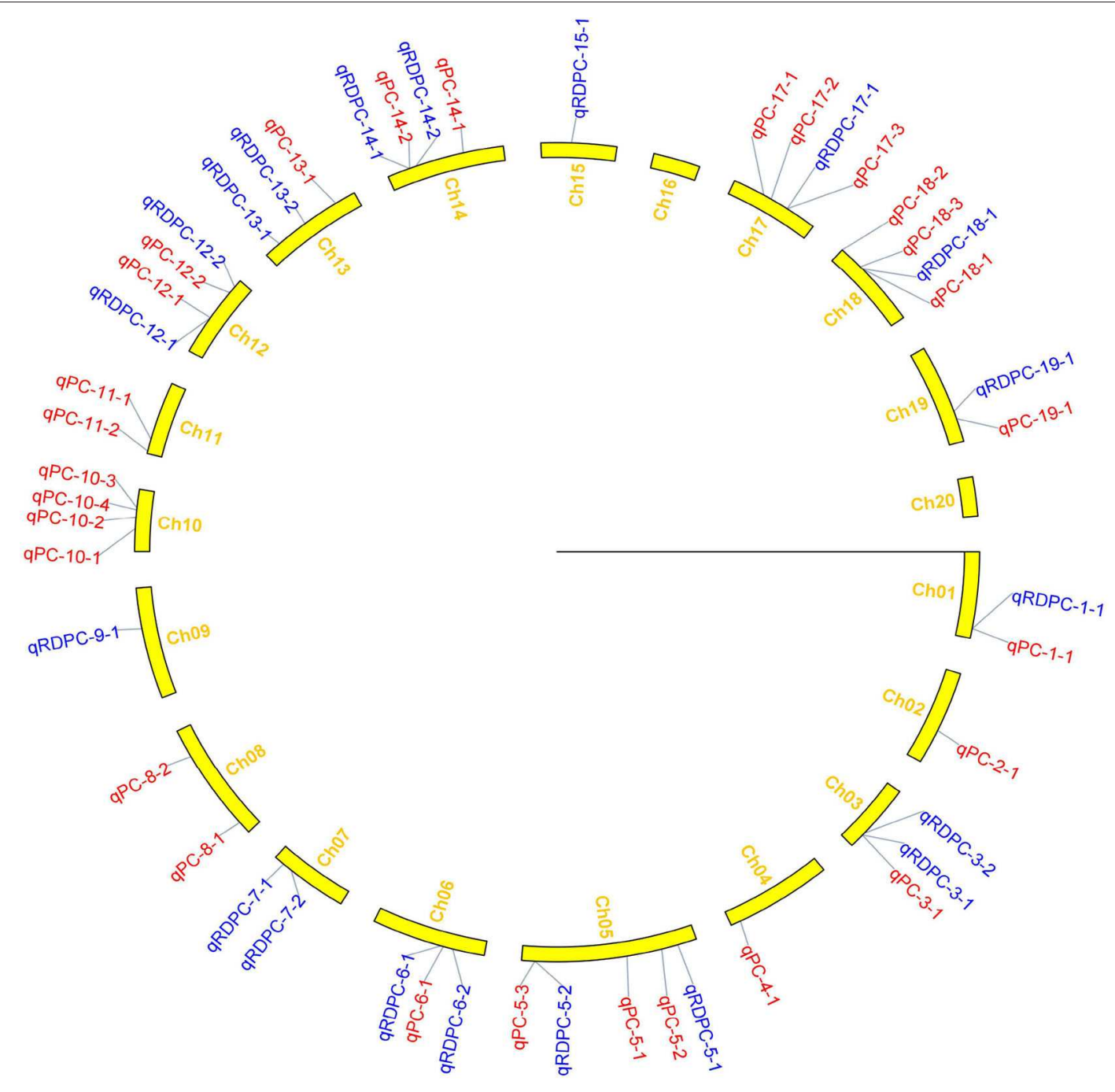

FIGURE 3 | Distribution of QTLs for protein content on linkage groups detected in the soybean FW-RIL population. Red and blue represent QTLs detected for protein content under different planting densities and the response of density difference, respectively.

oil content in soybean seeds (Table 2). The effect of environment on the response of protein and oil content to density was significant $(P \leq 0.01$; Table 3 ), indicating that the response of protein and oil content to planting density differed depending on the environment. In addition, the effect of increased planting density on protein and oil content varied markedly in terms of both direction and magnitude according to genotype (Figure 2). Therefore, we analyzed the effects of QTLs on protein and oil contents at different planting densities.

\section{QTLs for PC and OC at Two Planting Densities}

In this study, 65 QTLs associated with PC and OC were detected on 15 and 14 of the 20 soybean chromosomes under LOD value of 3 and under permutation method, respectively (Figures 3, 4), which 5 PC QTLs and 6 OC QTLs were located in two method. Of these, 28 PC QTLs (Table 4) and 37 OC QTLs (Table 5) were detected at different planting densities (D1 and D2). Among the QTLs detected, 14 for PC and 17 for OC were detected at $\mathrm{D} 1$. The $\mathrm{LOD}$ values ranged from 3.01 to 6.43 . A single QTL accounted for 5.22\% (qPC-17-2) to $14.58 \%$ (qOC-1-1) of phenotypic variance. The 14 remaining QTLs for PC and 20 QTLs for OC were detected at D2. The LOD values ranged from 3 to 8.93 . The PVE values of the QTLs ranged from $4.77 \%$ (qOC7-3) to $25.05 \%$ (qPC-6-1). Finally, 26 QTLs accounted for over $10 \%$ of the phenotypic variation. These findings indicate that protein and oil contents are controlled by both major-effect (PVE $\geq 10 \%$ ) and minor-effect (PVE $<10 \%$ ) QTLs (Figures 5, 6). Among these QTLs, only two QTLs (qOC-7-3, qOC-15-1) was simultaneously identified at both planting densities (Figure 7), indicating that the genetic basis for protein and oil content differed at different densities.

Of the QTLs detected, one protein-content QTLs (qPC-182) and three oil-content QTLs (qOC-18-1, qOC-10-1, qOC-5-1) 

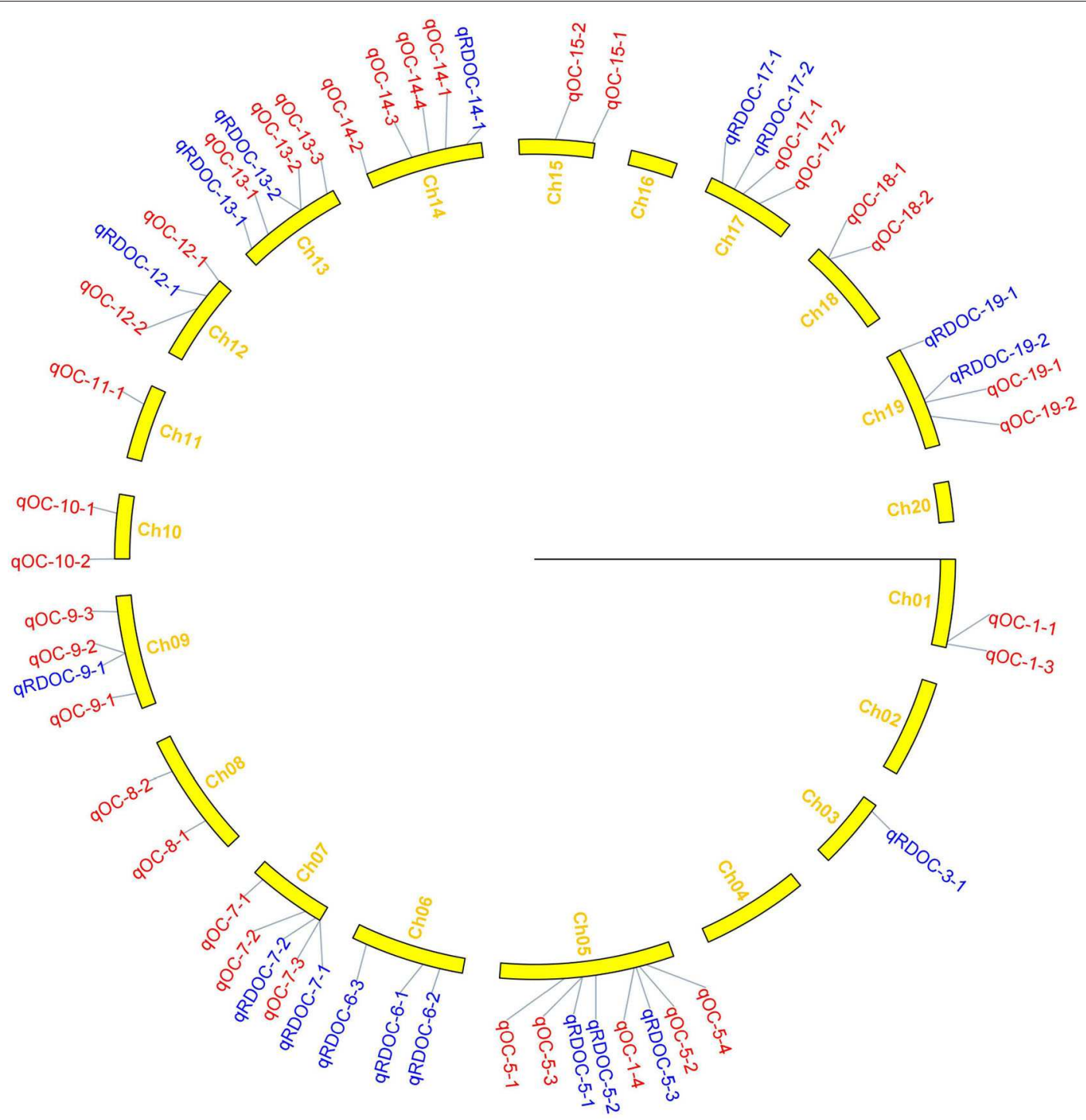

FIGURE 4 | Distribution of QTLs for oil content on linkage groups detected in the soybean FW-RIL population. Red and blue represent QTLs detected for oil content under different planting densities and the responses to density difference, respectively.

were detected in more than two environments with PVE of 6.87$9.16 \%$, while the 27 remaining protein-content QTLs and 34 oilcontent QTLs were detected in specific environments (D1: five PC QTLs and two OC in E1, three PC QTLs and two OC QTLs in E2, two PC QTLs and two OC QTLs in E3, two PC QTLs and five OC QTLs in E4, one PC QTLs and four OC QTLs in E5; D2: two PC QTLs and one OC QTLs in E1, one OC QTLs in E2, six PC QTLs and four OC QTLs in E3, two PC QTLs and six OC QTLs in E4, four PC QTLs and seven OC QTLs in E5). These results indicate that the genetic basis for protein and oil content differed in various environments (Figure 8).

Of the QTLs detected, there were 19, 9, 14 and 9 positive alleles that enhanced protein content in Kenfeng 14, Kenfeng 15, Heinong 48 and Kenfeng 19, respectively, and $15,15,17$ and 19 positive alleles that enhanced oil content in Kenfeng14, Kenfeng15, Heinong48 and Kenfeng19, respectively. Therefore, these QTLs increased the protein and oil contents in the soybean plants investigated (Figure S1).

\section{QTLs for Response to Density}

We identified 38 QTLs for the response of protein and oil content to density (RD) (Figures 3, 4) under LOD value of 3 and under permutation method, which 5 RDPC QTLs were located in two method. Briefly, 20 RD QTLs for protein content were identified on various chromosomes, including Chr01, Chr03, Chr05, Chr06, Chr07, Chr09, Chr12, Chr13, Chr14, Chr15, Chr17, Chr18, and Chr19, with LOD values ranging from 3.05 to 13.68 and accounting for a phenotypic variance of $3.64 \%$ (qRDPC3-2)-38.02\% (qRDPC-12-1). Moreover, 18 QTLs for oil content 


\begin{tabular}{|c|c|c|c|c|c|c|c|c|c|c|c|c|c|}
\hline Trait & $\begin{array}{l}\text { Planting } \\
\text { density }\end{array}$ & QTL & Method & Chromosome & Physical position (bp) & LOD & PVE $(\%)^{b}$ & Add $^{c}$ & Add $^{c}$ & Add $^{c}$ & ${\text { Add } 4^{c}}^{c}$ & Environment $^{d}$ & References \\
\hline \multirow[t]{15}{*}{ PC } & \multirow[t]{15}{*}{ D1 } & QPC-1-1 & ICIM-3 & 1 & $41,354,793-43,754,056$ & 3.01 & 7.06 & 0.23 & -0.34 & 0.56 & -0.46 & E4 & \\
\hline & & qPC-4-1 & $\mathrm{ICIM}-3$ & 4 & $16,292,606-41,180,931$ & 4.22 & 12.67 & -0.31 & 0.3 & 0.77 & -0.76 & E3 & \multirow[t]{2}{*}{ Stombaugh et al., 2004} \\
\hline & & qPC-5-2 & ICIM-3 & 5 & $3,379,706-3,450,946$ & 4.63 & 8.82 & -0.37 & 0.49 & 0.19 & -0.31 & E1 & \\
\hline & & qPC-8-1 & ICIM-3 & 8 & $276,792-15,554,288$ & 3.46 & 5.64 & -0.1 & -0.25 & 0.6 & -0.25 & E2 & $\begin{array}{l}\text { Tajuddin et al., 2003; Reinprecht } \\
\text { et al., 2006; Lu et al., 2013; Pathan } \\
\text { et al., } 2013\end{array}$ \\
\hline & & qPC-10-1 & ICIM-3 & 10 & $32,225,908-44,361,012$ & 3.16 & 6.7 & 0.67 & -0.46 & 0.29 & -0.5 & E5 & $\begin{array}{l}\text { Specht et al., 2001; Chen et al., } \\
\text { 2007; Mao et al., 2013; Qi et al., } 2014\end{array}$ \\
\hline & & qPC-10-2 & ICIM-3 & 10 & $44,570,190-45,647,371$ & 3.12 & 7.67 & 0.57 & -0.5 & 0.29 & -0.36 & E2 & Chen et al., 2007 \\
\hline & & qPC-10-3 & ICIM-3 & 10 & $44,665,252-45,076,309$ & 3.73 & 10.12 & 0.6 & 0.31 & -0.3 & -0.61 & E4 & Chen et al., 2007 \\
\hline & & qPC-10-4 & $\begin{array}{l}\text { ICIM- } \\
\text { 3/ICIM-P }\end{array}$ & 10 & $45,076,309-45,546,379$ & 6.43 & $12.4 / 7.19$ & $0.58 / 0.58$ & $-0.54 /-0.54$ & $0.33 / 0.33$ & $-0.37 /-0.37$ & E1 & \\
\hline & & qPC-11-2 & ICIM-3 & 11 & $3,507,011-7,091,516$ & 3.11 & 8.36 & 0.39 & -0.76 & 0.06 & 0.31 & E2 & $\begin{array}{l}\text { Brummer et al., 1997; Chapman } \\
\text { et al., 2003; Lu et al., 2013; Mao } \\
\text { et al., 2013 }\end{array}$ \\
\hline & & qPC-13-1 & ICIM-3 & 13 & $29,551,591-31,596,553$ & 3.6 & 6.96 & -0.66 & 0.01 & 0.26 & 0.39 & E3 & Mao et al., 2013 \\
\hline & & qPC-17-1 & ICIM-3 & 17 & $188,378-36,960,374$ & 3.19 & 5.42 & 0.52 & -0.5 & 0.02 & -0.05 & E1 & $\begin{array}{l}\text { Reinprecht et al., 2006; Mao et al., } \\
\text { 2013; Wang et al., 2014b }\end{array}$ \\
\hline & & qPC-17-2 & ICIM-3 & 17 & $34,150,351-35,150,689$ & 3.31 & 5.22 & 0.55 & -0.46 & -0.06 & -0.03 & E1 & Mao et al., 2013 \\
\hline & & \multirow[t]{2}{*}{ qPC-18-2 } & ICIM-3 & 18 & $6,442,474-6,652,232$ & 4.32 & 7.72 & -0.34 & 0.31 & -0.38 & 0.41 & E1 & \multirow[t]{2}{*}{ Mao et al., 2013} \\
\hline & & & $\mathrm{ICIM}-3$ & & & 4.76 & 8.1 & -0.6 & 0.46 & -0.27 & 0.41 & E2 & \\
\hline & & qPC-18-3 & ICIM-3 & 18 & $8,261,351-12,546,166$ & 3.64 & 6.26 & -0.53 & 0.13 & 0.1 & 0.31 & E1 & Reinprecht et al., 2006 \\
\hline \multirow[t]{14}{*}{ PC } & \multirow[t]{14}{*}{ D2 } & qPC-2-1 & ICIM-3 & 2 & $43,360,376-47,381,537$ & 3.05 & 5.62 & 0.09 & 0.64 & -0.43 & -0.29 & E3 & Qi et al., 2014 \\
\hline & & qPC-3-1 & ICIM-3 & 3 & $1,393,672-1,560,122$ & 3.13 & 10.47 & 0.3 & 0.29 & 0.13 & -0.72 & E4 & \\
\hline & & qPC-5-1 & $\mathrm{ICIM}-3$ & 5 & $34,050,351-34,241,321$ & 3.38 & 6.02 & -0.14 & -0.43 & -0.01 & 0.58 & E5 & \\
\hline & & qPC-5-3 & ICIM-3 & 5 & $30,826,149-40,096,192$ & 3.82 & 13.25 & 0.44 & -0.82 & 0.41 & -0.03 & E4 & Jun et al., 2008; Pathan et al., 2013 \\
\hline & & qPC-6-1 & $\begin{array}{l}\text { ICIM- } \\
\text { 3/ICIM-P }\end{array}$ & 6 & $47,860,433-49,004,869$ & 8.93 & $25.05 / 23.14$ & $1.46 / 1.46$ & $0.53 / 0.53$ & $-0.99 /-0.99$ & $-1 /-1$ & E3 & Csanádi et al., 2001 \\
\hline & & qPC-8-2 & ICIM-3 & 8 & $3,050,275-3,253,888$ & 3.28 & 6.99 & 0.36 & -0.55 & -0.29 & 0.49 & E3 & \\
\hline & & qPC-11-1 & $\begin{array}{l}\text { ICIM- } \\
\text { 3/ICIM-P }\end{array}$ & 11 & $3,507,011-33,288,769$ & 5.86 & 11.48/9.11 & $0.69 / 0.69$ & $-0.11 /-0.11$ & $0.23 / 0.23$ & $-0.82 /-0.82$ & E5 & \multirow{6}{*}{$\begin{array}{l}\text { Brummer et al., 1997; Chapman } \\
\text { et al., 2003; Reinprecht et al., 2006; } \\
\text { Gai et al., 2007; Lu et al., 2013; Mao } \\
\text { et al., 2013; Wang et al., 2014b; } \\
\text { Asekova et al., } 2016\end{array}$} \\
\hline & & qPC-12-1 & $\begin{array}{l}\text { ICIM- } \\
\text { 3/ICIM-P }\end{array}$ & 12 & $16,850,384-16,953,996$ & 5.11 & $12.6 / 11.64$ & $0.46 / 0.46$ & $-0.78 /-0.78$ & $-0.37 /-0.37$ & $0.69 / 0.69$ & E3 & \\
\hline & & qPC-12-2 & ICIM-3 & 12 & $2,151,310-2,257,434$ & 3.12 & 5.42 & -0.28 & 0 & -0.31 & 0.59 & E5 & \\
\hline & & qPC-14-1 & ICIM-3 & 14 & $13,471,993-16,178,681$ & 3.00 & 10.3 & 0.56 & -0.01 & -0.37 & -0.18 & E1 & \\
\hline & & qPC-14-2 & ICIM-3 & 14 & $2,256,954-4,780,532$ & 4.13 & 7.08 & 0.73 & 0 & -0.19 & -0.54 & E5 & \\
\hline & & qPC-17-3 & ICIM-3 & 17 & $39,258,351-39,557,300$ & 3.96 & 12.75 & -0.01 & -0.38 & -0.24 & 0.63 & E1 & \\
\hline & & qPC-18-1 & $\begin{array}{l}\text { ICIM- } \\
\text { 3/ICIM-P }\end{array}$ & 18 & $12,546,166-55,369,435$ & 5.93 & $13.93 / 12.87$ & $0.77 / 0.77$ & $-0.74 /-0.74$ & $0.5 / 0.5$ & $-0.54 /-0.54$ & E3 & $\begin{array}{l}\text { Diers et al., 1992; Brummer et al., } \\
\text { 1997; Jun et al., 2008; Eskandari } \\
\text { et al., 2013; Lu et al., 2013; Mao } \\
\text { et al., } 2013\end{array}$ \\
\hline & & qPC-19-1 & ICIM-3 & 19 & $251,932-48,432,343$ & 3.21 & 6.67 & 0.37 & 0.38 & 0.04 & -0.79 & E3 & $\begin{array}{l}\text { Diers et al., 1992; Mansur et al., } \\
\text { 1996; Orf et al., 1999; Chapman } \\
\text { et al., 2003; Tajuddin et al., 2003; } \\
\text { Eskandari et al., 2013; Lu et al., 2013; } \\
\text { Mao et al., 2013; Asekova et al., 2016 }\end{array}$ \\
\hline
\end{tabular}

${ }^{a} D 1$, the first (lower) planting density $\left(2.15 \times 10^{5}\right.$ plants ha $\left.{ }^{-1}\right), D 2:$ the second (height) planting density $\left(3.0 \times 10^{5}\right.$ plants ha $\left.a^{-1}\right)$.

${ }^{b} P V E$, phenotypic variation explained.

${ }^{c}$ Add1, Add2, Add3, Add4, additive effects from Kenfeng14, Kenfeng15, Heinong48, Kenfeng19, respectively. Additive effect over than $0.05 \%$ are positive alleles.

${ }^{d}$ E1: Harbin in 2015; E2: Keshan in 2015; E3: Acheng in 2016; E4: Shuangcheng in 2016; E5: Harbin in 2016. 
TABLE 5 | QTLs for oil content (qOC) identified under different planting densities in different environments.

\begin{tabular}{|c|c|c|c|c|c|c|c|c|c|c|c|c|c|}
\hline Trait & $\begin{array}{l}\text { Planting } \\
\text { density }^{\mathrm{a}}\end{array}$ & QTL & Method & Chromosome & e Physical position (bp) & LOD & PVE $(\%)^{b}$ & Add $^{c}{ }^{c}$ & $\operatorname{Add}^{c}$ & Add $^{c}$ & Add $^{c}{ }^{c}$ & Environment $^{d}$ & dReferences \\
\hline \multirow[t]{20}{*}{ OC } & D1 & qOC-1-1 & ICIM-3/ICIM-P & 1 & $27,421,201-27,657,396$ & 5.35 & $8.70 / 8.95$ & $-0.14 /-0.14$ & $0.13 / 0.13$ & $-0.25 /-0.25$ & $0.26 / 0.26$ & E1 & Hyten et al., 2004 \\
\hline & & & & & & 5.35 & $14.58 / 8.86$ & $-0.14 /-0.14$ & $0.13 / 0.13$ & $-0.25 /-0.25$ & $0.26 / 0.26$ & E1 & \\
\hline & & qOC-5-2 & ICIM-3 & 5 & $3,379,706-3,450,946$ & 3.11 & 6.45 & 0.09 & -0.4 & 0.34 & -0.04 & E2 & Wang et al., 2014b \\
\hline & & qOC-5-4 & ICIM-3 & 5 & $2,209,578-4,202,110$ & 3.02 & 5.9 & -0.33 & -0.28 & 0.65 & -0.05 & E2 & $\begin{array}{l}\text { Wang et al., 2014b; Han et al., } \\
2015\end{array}$ \\
\hline & & qOC-7-1 & ICIM-3 & 7 & 1,974,268-2,303,275 & 3.96 & 8.59 & 0.07 & -0.14 & -0.19 & 0.25 & E4 & \\
\hline & & qOC-7-2 & ICIM-3/ICIM-P & 7 & $38,265,631-38,555,656$ & 5.72 & $9.79 / 9.51$ & $-0.14 /-0.14$ & $0.23 / 0.23$ & $0.12 / 0.12$ & $-0.21 /-0.21$ & E1 & Tajuddin et al., 2003 \\
\hline & & qOC-7-3 & ICIM-3 & 7 & $39,411,702-40,613,918$ & 3.56 & 8.63 & 0.21 & 0.15 & -0.08 & -0.27 & E4 & Tajuddin et al., 2003 \\
\hline & & qOC-8-1 & ICIM-3 & 8 & $25,108,271-33,158,058$ & 3.73 & 12.03 & -0.23 & -0.15 & 0.13 & 0.25 & E5 & Chen et al., 2007 \\
\hline & & qOC-9-1 & ICIM-3 & 9 & $3,352,797-4,194,469$ & 3.77 & 11.83 & -0.18 & 0.2 & -0.2 & 0.19 & E5 & $\begin{array}{l}\text { Mansur et al., 1996; Mao et al., } \\
2013\end{array}$ \\
\hline & & qOC-10-1 & ICIM-3 & 10 & $44,665,252-45,076,309$ & 4.2 & 7.11 & -0.18 & 0.18 & -0.16 & 0.16 & E1 & \\
\hline & & & & & & 3.26 & 8.67 & -0.3 & 0.38 & -0.21 & 0.12 & E2 & \\
\hline & & qOC-12-2 & ICIM-3 & 12 & $9,150,278-9,461,950$ & 3.18 & 10.07 & 0.23 & 0.13 & -0.13 & -0.22 & E5 & \\
\hline & & qOC-13-1 & ICIM-3 & 13 & $2,267,617-17,851,239$ & 3.98 & 9.97 & -0.14 & 0.2 & -0.25 & 0.19 & E4 & Qi et al., 2011a \\
\hline & & qOC-13-3 & ICIM-3 & 13 & $5,680,211-36,010,071$ & 3.35 & 7.59 & -0.18 & -0.07 & 0.37 & -0.12 & E4 & $\begin{array}{l}\text { Qi et al., 2011a; Eskandari et al. } \\
\text { 2013; Wang et al., 2014b }\end{array}$ \\
\hline & & qOC-14-4 & ICIM-3 & 14 & $8,780,886-16,178,681$ & 3.25 & 9.2 & 0.01 & 0 & 0.22 & -0.23 & E5 & $\begin{array}{l}\text { Tajuddin et al., 2003; Qi et al., } \\
\text { 2011a; Rossi et al., } 2013\end{array}$ \\
\hline & & qOC-15-1 & ICIM-3 & 15 & $12,793,869-12,867,460$ & 3.07 & 11.95 & -0.16 & 0.07 & -0.19 & 0.28 & E3 & Chen et al., 2007 \\
\hline & & qOC-18-1 & ICIM-3/ICIM-P & 18 & $3,253,447-3,422,683$ & 5.3 & $8.89 / 9.16$ & $0.21 / 0.21$ & $-0.07 /-0.07$ & $0.13 / 0.13$ & $-0.28 /-0.28$ & E1 & \\
\hline & & & & & & 3.36 & 7.5 & 0.28 & -0.02 & 0.14 & -0.39 & E2 & \\
\hline & & qOC-19-1 & ICIM-3 & 19 & $44,754,259-45,487,455$ & 3.27 & 11.26 & 0.24 & 0.02 & -0.26 & 0 & E3 & Hyten et al., 2004 \\
\hline & & qOC-19-2 & ICIM-3 & 19 & 48,060,796-48,698,594 & 3.4 & 7.01 & 0.25 & -0.06 & -0.21 & 0.01 & E4 & \\
\hline \multirow[t]{7}{*}{ OC } & D2 & qOC-1-3 & ICIM-3/ICIM-P & 1 & $36,970,568-40,053,928$ & 8.47 & $15.84 / 10.94$ & $-0.44 /-0.44$ & $0.26 / 0.26$ & $-0.14 /-0.14$ & $0.31 / 0.31$ & E4 & $\begin{array}{l}\text { Hyten et al., 2004; Qi et al., } \\
\text { 2011a }\end{array}$ \\
\hline & & qOC-1-4 & ICIM-3 & 1 & $51,928,667-52,201,376$ & 3.57 & 9.73 & 0.17 & 0.11 & 0.11 & -0.4 & E3 & Eskandari et al., 2013 \\
\hline & & qOC-5-1 & ICIM-3 & 5 & 25,952,089-26,680,891 & 3.06 & 6.87 & -0.06 & -0.1 & 0.25 & -0.09 & E1 & $\begin{array}{l}\text { Mansur et al., 1996; Qi et al., } \\
\text { 2011a; Rossi et al., 2013; Han } \\
\text { et al., } 2015\end{array}$ \\
\hline & & & & & & 3.2 & 9.09 & -0.28 & -0.1 & 0.42 & -0.04 & E2 & \\
\hline & & qOC-5-3 & ICIM-3 & 5 & $32,194,294-34,580,644$ & 4.11 & 14.74 & -0.01 & -0.12 & 0.36 & -0.23 & E1 & $\begin{array}{l}\text { Lark et al., 1994; Brummer et al } \\
1997\end{array}$ \\
\hline & & qOC-7-3 & ICIM-3 & 7 & $39,411,702-40,613,918$ & 3 & 4.77 & 0.18 & 0.03 & -0.26 & 0.05 & E4 & Tajuddin et al., 2003 \\
\hline & & qOC-8-2 & ICIM-3 & 8 & $3,769,173-4,265,916$ & 3.32 & 5.24 & -0.13 & -0.03 & -0.14 & 0.29 & E4 & \\
\hline
\end{tabular}




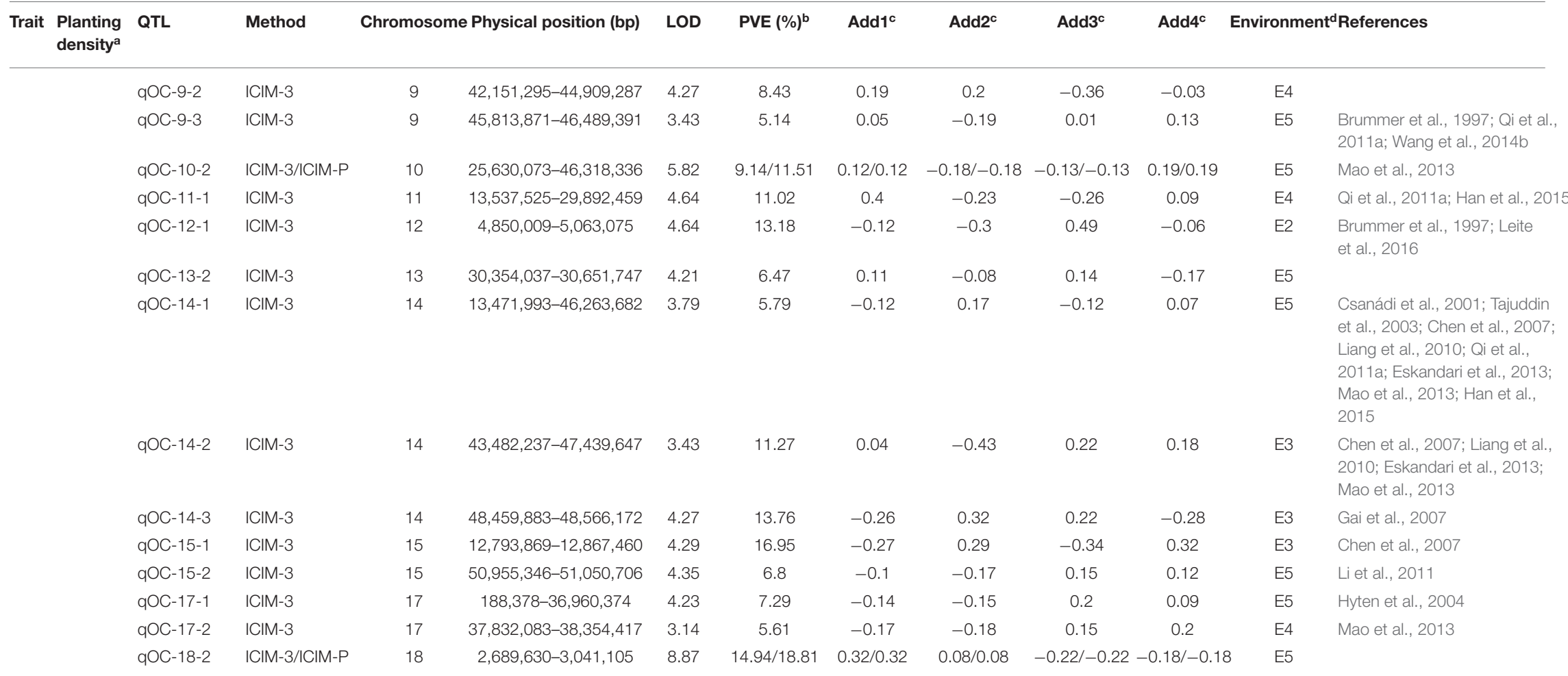

${ }^{a} D 1$ : the first (lower) planting density $\left(2.15 \times 105\right.$ plants ha $\left.{ }^{-1}\right)$, D2: the second (higher) planting density $\left(3 \times 105\right.$ plants ha $\left.{ }^{-1}\right)$.

${ }^{b} P V E$, phenotypic variation explained.

${ }^{c}$ Add1, Add2, Add3, Add4: additive effects from Kenfeng14, Kenfeng15, Heinong48, Kenfeng19, respectively. Additive effect over than $0.05 \%$ are positive alleles.

${ }^{d}$ E1: Harbin in 2015; E2: Keshan in 2015; E3: Acheng in 2016; E4: Shuangcheng in 2016; E5: Harbin in 2016. 


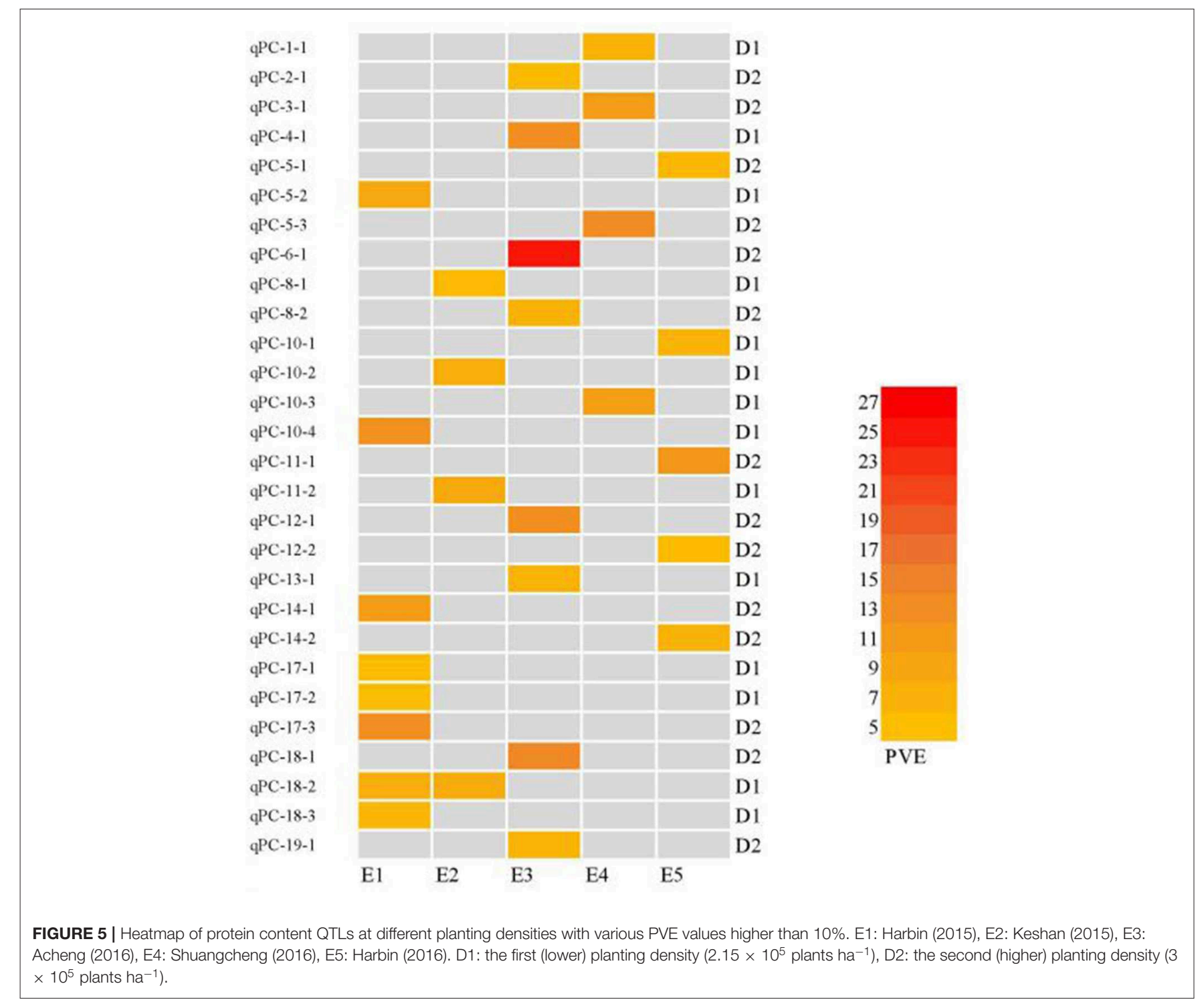

were located on 10 different chromosomes. The PVE values of single QTLs for oil content ranged from 5.88\% (qRDOC-7-2) to $24.68 \%$ (qRDOC-6-2), with a LOD value ranging from 3.04 to 4.85 (Table 6). There were 19 RD QTLs with a PVE $>10 \%$, indicating that the $\mathrm{RD}$ trait is controlled by both major-effect and minor-effect QTLs (Figure 9). Among the RD QTLs, one QTL for protein content were detected in two environments, and the 19 remaining RD QTLs for protein content and 18 for oil content were environment specific (Figure 10). The finding that not all RD QTLs were detected in all environments might explain the differences in protein and oil contents in response to planting density.

Among the RD QTLs, 11, 8, 12 and 9 positive alleles from Kenfeng14, Kenfeng15, Heinong48 and Kenfeng19, respectively increased the protein content at higher planting density. Similarly, 8, 13, 6 and 7 positive alleles from Kenfeng14, Kenfeng15, Heinong48 and Kenfeng19, respectively increased the oil content when the density increased from D1 to D2 (Figure S1).

\section{Analysis of Potential Candidate Genes}

We identified 484 genes based on 23 QTLs under different planting densities and with the responses to density difference. Seventy-six genes were highly expressed within these regions in seeds, with 26 annotated genes in 20 pathways and 3 protein families identified in the KEGG database (Figure 11). Among these, four genes were selected as potential candidate genes affecting protein and oil content due to their annotations and functions in various metabolic pathways (Table 7; see bold text).

\section{DISCUSSION}

\section{QTLs With Effects on Protein and Oil Content in Soybean at Different Planting Densities}

Protein and oil contents are quantitative traits that are affected by environmental conditions. Competition for nutritional resources occurs when the planting density changes, and different plant 


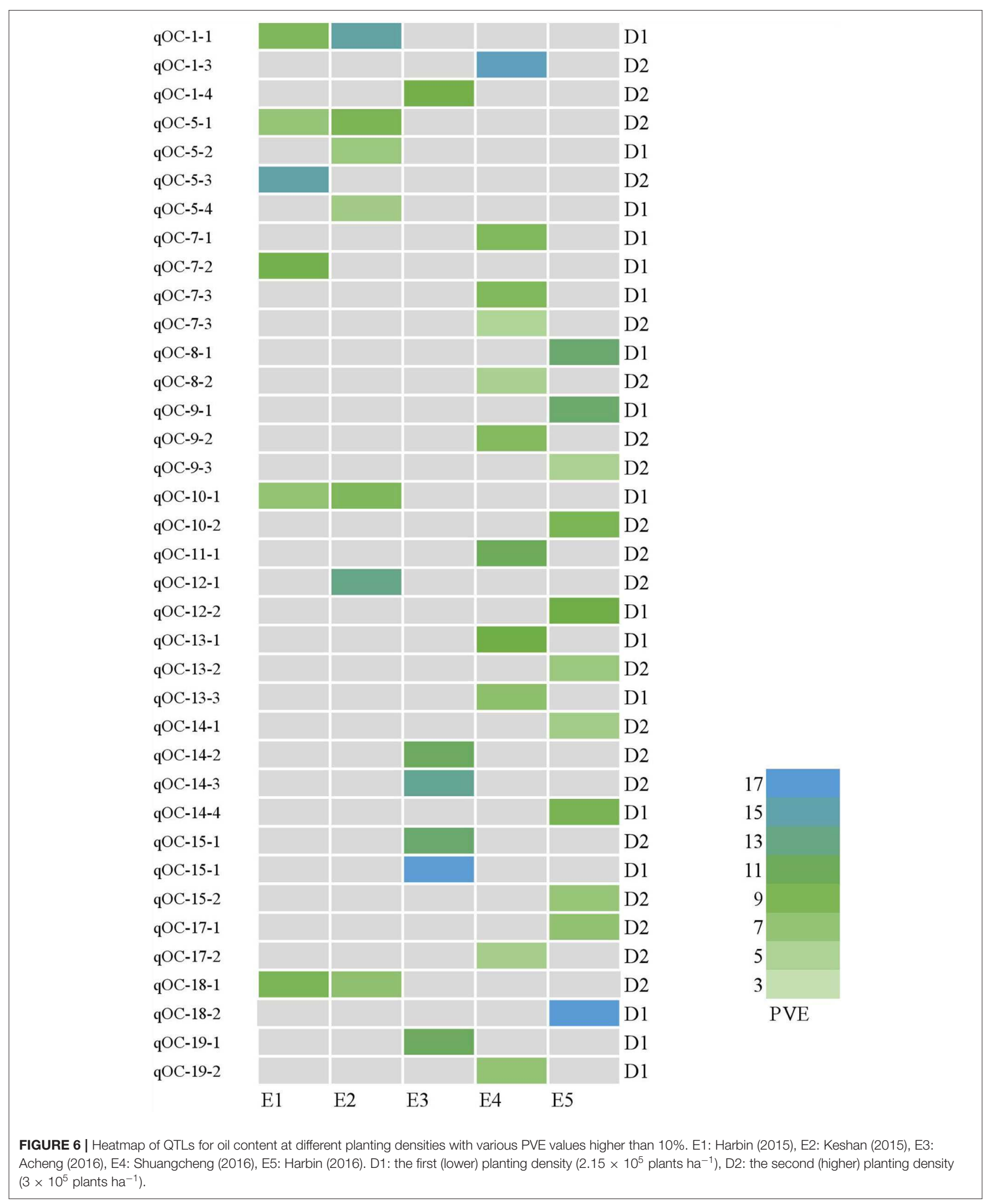



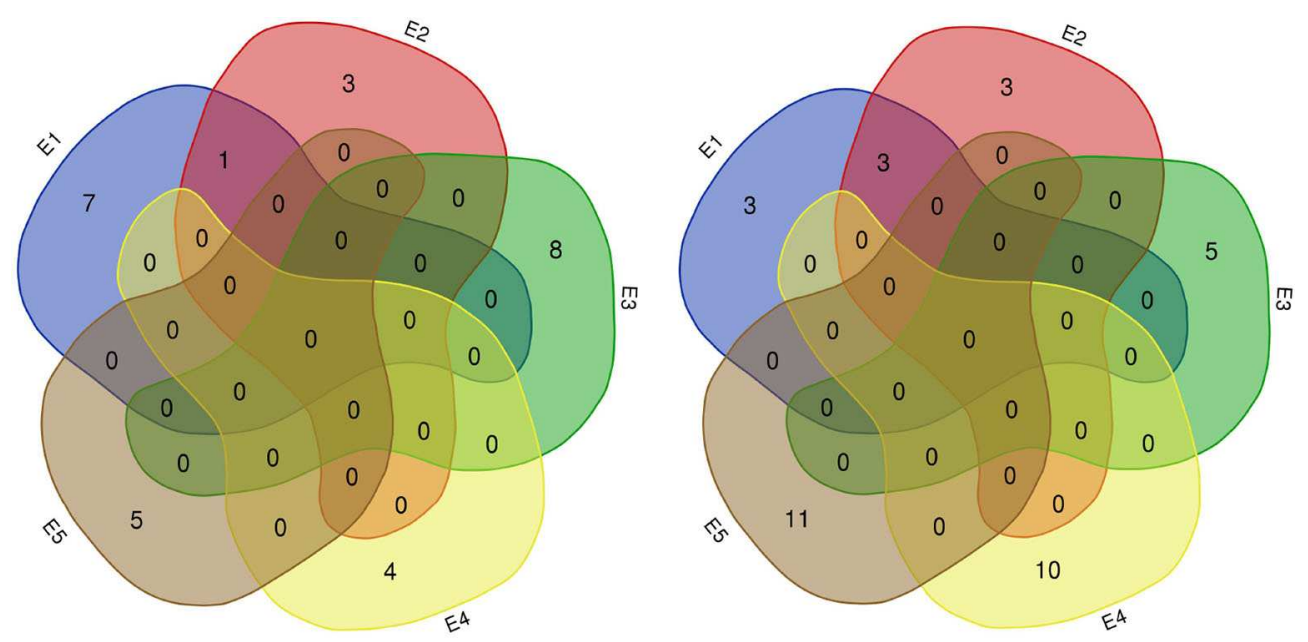

FIGURE 7 | Number of QTLs for protein (left) and oil (right) content detected in five environments. E1: Harbin (2015), E2: Keshan (2015), E3: Acheng (2016), E4: Shuangcheng (2016), E5: Harbin (2016).
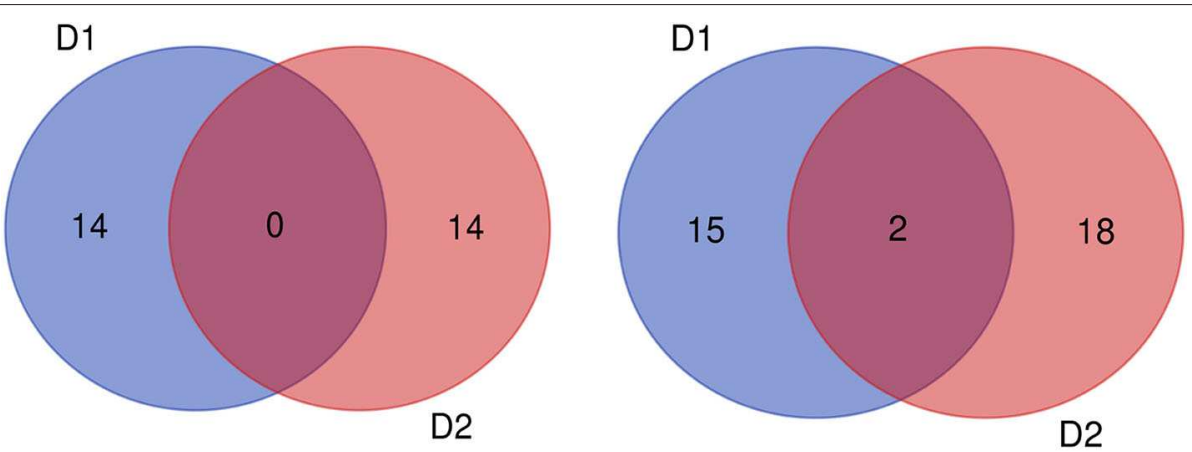

FIGURE 8 | Number of QTLs for protein (left) and oil (right) content detected under two planting densities. D1: the first (lower) planting density (2.15 $\times 10^{5}$ plants $\left.\mathrm{ha}^{-1}\right)$, D2: the second (higher) planting density $\left(3 \times 10^{5}\right.$ plants ha $\left.{ }^{-1}\right)$.

varieties can respond differently. In the current study, the protein content of four soybean varieties and the oil content of five soybean varieties increased when the planting density increased from D1 to D2 in five environments (Figure 2). However, the responses of the remaining varieties to density were inconsistent, indicating that the environment affects the expression of genes that control protein and oil content. Bellaloui et al. (2014) used four soybean varieties to study the effects of planting density on protein and oil content. The protein contents of soybean varieties P93M90, AG 3906, P94B73, and V52N3 reached their maximum levels at a planting density of 518,700,518,700, 180,000, and 150,000 plants $\mathrm{ha}^{-1}$, respectively. Similarly, the oil contents of the four varieties were highest at a planting density of 247,000 , $444,600,150,000$, and 60,000 plants $\mathrm{ha}^{-1}$, respectively. These results indicate that the responses of individual protein and oil contents vary depending on the planting density. Therefore, the results of the present study are in agreement with those reported by Bellaloui et al. (2014).

Similar to the physiological responses to abiotic stresses, such as water deficiency, waterlogging, low phosphorus levels, cold temperatures, and light and nitrogen deficiency, a specific molecular mechanism also controls the responses of protein and oil content to increasing planting density (Osman et al., 2013). There are two aspects of the genetic basis of the effects of QTLs on the variation of protein and oil content at increasing planting density. First, the cumulative effects of QTLs could be detected directly based on protein and oil contents at a specific density in a particular environment. Here, these phenotypic values reflect the cumulative effects of genotype, macro-environment (location and years), interactions between genotype and environment, and planting density. The results of QTL mapping of the same trait can vary in different environments. Ku et al. (2015) evaluated the effects of two different planting densities (60,000 and 120,000 plant $/ \mathrm{hm}^{2}$ ) on three plant height-related traits (plant height, ear height, and ear height-to-plant height ratio) in maize. Nine QTLs were detected at the low planting density, and seven QTLs were detected at the high planting density. Akond et al. (2012) used a RIL population derived from a cross between soybean lines PI 438489B and Hamilton to detect QTLs for PC and OC under two planting densities. Three QTLs for protein content were detected 
TABLE 6 | RD QTLs for protein and oil content under different planting densities.

\begin{tabular}{|c|c|c|c|c|c|c|c|c|c|c|c|}
\hline QTL $^{\mathbf{a}}$ & Method & Chromosome & Physical position (bp) & LOD & PVE $(\%)^{b}$ & Add $^{c}{ }^{c}$ & Add2 $^{c}$ & Add $^{c}$ & $\operatorname{Add}^{c}$ & Environment $^{d}$ & References \\
\hline qRDPC-1-1 & ICIM-3 & 1 & $41,354,793-43,754,056$ & 3.16 & 10.3 & -0.22 & -0.42 & 0.14 & 0.5 & E1 & \\
\hline qRDPC-3-1 & ICIM-3 & 3 & $1,393,672-1,560,122$ & 3.13 & 6.44 & 0.21 & 0.17 & 0.17 & -0.55 & E4 & \\
\hline qRDPC-3-2 & ICIM-3 & 3 & $3,053,942-3,250,514$ & 3.1 & 3.64 & -0.03 & -0.35 & 0.69 & -0.32 & E3 & \\
\hline qRDPC-5-1 & ICIM-3 & 5 & $3,894,485-32,350,213$ & 3.14 & 7.86 & -0.19 & -0.68 & 0.43 & 0.44 & E2 & Mansur et al., 1996; Mao et al., 2013 \\
\hline qRDPC-5-2 & ICIM-3 & 5 & $30,826,149-40,096,192$ & 3.05 & 9.1 & 0.42 & -0.43 & 0.44 & -0.43 & E4 & Jun et al., 2008; Pathan et al., 2013 \\
\hline qRDPC-6-1 & ICIM-3/ICIM-P & 6 & $47,553,280-47,860,433$ & 6.71 & $10.87 / 12.42$ & $0.93 / 0.93$ & $0.47 / 0.47$ & $-0.76 /-0.76$ & $-0.64 /-0.64$ & E3 & Csanádi et al., 2001; Hyten et al., 2004 \\
\hline qRDPC-6-2 & ICIM-3 & 6 & $49,930,570-50,252,758$ & 3.24 & 5.06 & -1.28 & 0.31 & 0.6 & 0.37 & E3 & \\
\hline qRDPC-7-1 & ICIM-3/ICIM-P & 7 & $1,974,268-2,303,275$ & 6.28 & $10.92 / 13.12$ & $-0.66 /-0.66$ & $0.53 / 0.53$ & $0.68 / 0.68$ & $-0.55 /-0.55$ & E5 & Mao et al., 2013 \\
\hline qRDPC-7-2 & ICIM-3 & 7 & $451,458-511,687$ & 4.76 & 7.61 & 0.27 & -0.72 & -0.04 & 0.49 & E5 & \\
\hline qRDPC-9-1 & ICIM-3 & 9 & $4,674,753-14,751,759$ & 3.41 & 7.04 & -0.85 & 0.22 & 0.35 & 0.28 & E5 & Specht et al., 2001 \\
\hline qRDPC-12-1 & ICIM-3/ICIM-P & 12 & $16,850,384-16,953,996$ & 13.68 & $33.26 / 38.02$ & $1.15 / 1.15$ & $-1.44 /-1.14$ & $-0.79 /-0.79$ & $1.08 / 1.08$ & E3 & \\
\hline qRDPC-12-2 & ICIM-3 & 12 & $3,175,045-4,701,685$ & 3.14 & 6.37 & -0.25 & -0.15 & 0.64 & -0.23 & E4 & Liang et al., 2010 \\
\hline qRDPC-13-1 & ICIM-3/ICIM-P & 13 & $15,750,139-16,469,296$ & 5.94 & $9.98 / 11.41$ & $0.42 / 0.42$ & $-0.78 /-0.78$ & $-0.34 / 0.34$ & $0.71 / 0.71$ & E3 & Mao et al., 2013 \\
\hline qRDPC-13-2 & ICIM-3/ICIM-P & 13 & $444,838-43,052,819$ & 7.73 & $13.36 / 15.27$ & $-1.03 /-1.03$ & $0.74 / 0.74$ & $-0.41 /-0.41$ & $0.7 / 0.7$ & E3 & Mao et al., 2013 \\
\hline \multirow[t]{2}{*}{ qRDPC-14-1 } & ICIM-3 & 14 & $2,256,954-4,780,532$ & 3.55 & 8.06 & 0.52 & -1.09 & 0.21 & 0.37 & E3 & Akond et al., 2014 \\
\hline & & & & 3.76 & 6.62 & 0.68 & 0.16 & -0.24 & -0.6 & E5 & \\
\hline qRDPC-14-2 & ICIM-3 & 14 & $4,450,691-4,558,092$ & 4.67 & 10.74 & 0.62 & -0.36 & 0.32 & -0.58 & E4 & Akond et al., 2014 \\
\hline qRDPC-15-1 & ICIM-3 & 15 & $51,351,343-51,546,757$ & 4.96 & 10.87 & 0.4 & 0.43 & -0.02 & -0.81 & E4 & \\
\hline QRDPC-17-1 & ICIM-3 & 17 & $39,258,351-39,557,300$ & 4.28 & 13.73 & 0 & -0.41 & -0.23 & 0.64 & E1 & $\begin{array}{l}\text { Tajuddin et al., 2003; Warrington et al., } \\
2015\end{array}$ \\
\hline QRDPC-18-1 & ICIM-3 & 18 & $12,546,166-55,369,435$ & 3.67 & 10.93 & 0.33 & -0.34 & 0.58 & -0.58 & E4 & $\begin{array}{l}\text { Diers et al., 1992; Brummer et al., 1997; } \\
\text { Jun et al., 2008; Liang et al., 2010; Lu } \\
\text { et al., 2013; Mao et al., } 2013\end{array}$ \\
\hline QRDPC-19-1 & ICIM-3 & 19 & $47,453,417-47,560,466$ & 3.8 & 6.04 & 0.5 & 0.4 & -0.26 & -0.64 & E3 & \\
\hline qRDOC-3-1 & ICIM-3 & 3 & $31,574,922-31,782,255$ & 3.81 & 18.13 & -0.27 & 0.82 & -0.21 & -0.34 & E3 & Mao et al., 2013 \\
\hline qRDOC-5-1 & ICIM-3 & 5 & 32,194,294-34,580,644 & 3.24 & 10.79 & -0.02 & -0.09 & 0.32 & -0.21 & E1 & Lark et al., 1994; Brummer et al., 1997 \\
\hline qRDOC-5-2 & ICIM-3 & 5 & $35,250,550-35,462,154$ & 3.36 & 10.53 & -0.12 & 0.22 & -0.18 & 0.07 & E5 & \\
\hline qRDOC-5-3 & ICIM-3 & 5 & 37,674,734-38,453,062 & 3.38 & 8.89 & 0.12 & 0.21 & -0.76 & 0.43 & E4 & \\
\hline qRDOC-6-1 & ICIM-3 & 6 & $49,304,240-49,371,230$ & 3.07 & 6.25 & -0.04 & 0.05 & -0.22 & 0.21 & E2 & \\
\hline qRDOC-6-2 & ICIM-3 & 6 & $50,554,375-50,757,507$ & 4.2 & 24.68 & -0.03 & 0.26 & 0.17 & -0.4 & E3 & \\
\hline qRDOC-6-3 & ICIM-3 & 6 & 7,359,493-7,951,010 & 4.85 & 17.67 & -0.32 & 0.12 & 0.25 & -0.05 & E5 & Pathan et al., 2013 \\
\hline qRDOC-7-1 & ICIM-3 & 7 & $39,411,702-40,613,918$ & 3.23 & 6.55 & 0.08 & 0.2 & -0.38 & 0.09 & E4 & Tajuddin et al., 2003 \\
\hline qRDOC-7-2 & ICIM-3 & 7 & $40,281,053-41,513,649$ & 3.36 & 5.88 & -0.32 & 0.12 & -0.11 & 0.32 & E4 & Tajuddin et al., 2003 \\
\hline qRDOC-9-1 & ICIM-3 & 9 & $42,151,295-44,909,287$ & 3.1 & 6.75 & 0.16 & 0.25 & -0.4 & -0.01 & E4 & Mao et al., 2013 \\
\hline qRDOC-12-1 & ICIM-3 & 12 & $1,650,694-1,753,755$ & 3.34 & 16.42 & -0.13 & 0.34 & -0.24 & 0.03 & E3 & Leite et al., 2016 \\
\hline qRDOC-13-1 & ICIM-3 & 13 & $21,697,193-24,456,483$ & 3.27 & 10.3 & 0.19 & 0.02 & -0.37 & 0.16 & E2 & \\
\hline qRDOC-13-2 & ICIM-3 & 13 & $29,667,064-30,760,581$ & 3.95 & 10.89 & 0.2 & 0.01 & 0.04 & -0.24 & E5 & \\
\hline
\end{tabular}




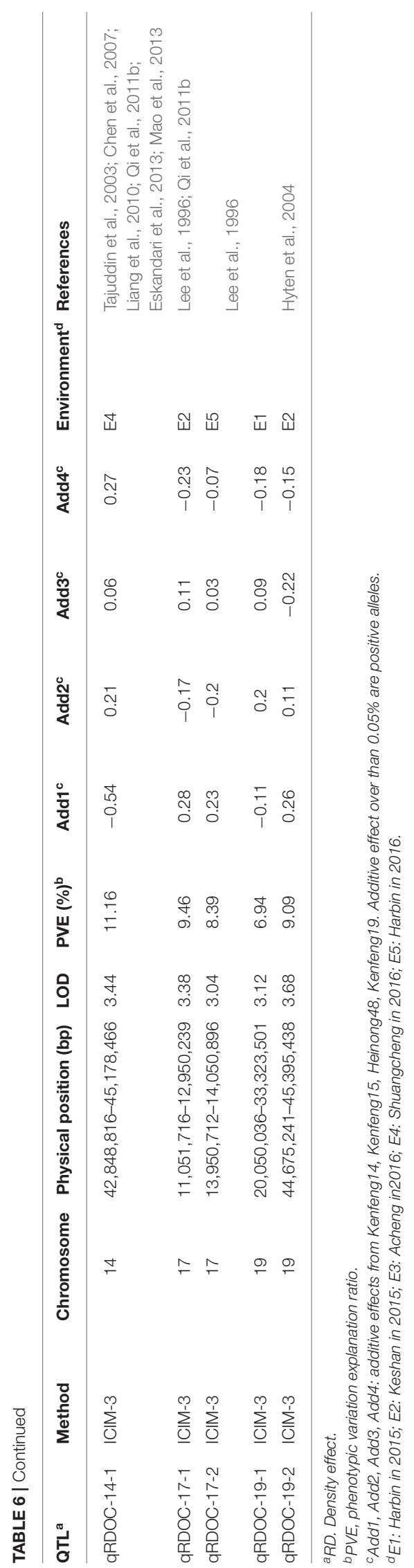

at a low planting density ( $50 \mathrm{~cm}$ row space), while 2 QTLs for protein content and 6 QTLs for oil content were detected at a high planting density $(25 \mathrm{~cm}$ row space). In the current study, we used an FW-RIL population to detect density-specific QTLs for protein and oil content. We identified 28 protein-content QTLs and 35 oil-content QTLs at planting densities D1 and D2, respectively. Among these QTLs, two QTLs was identified at both planting densities, whereas the remaining QTLs were detected at different densities. These results indicate that the genetic basis for the cumulative effects of QTLs on protein and oil content under two densities strongly differed, as indicated by significant genotype by density interaction effects $(P \leq 0.01$; Table 2$)$.

Second, the net effects of QTLs on planting density could be identified based on increases in protein and oil content in response to density. To analyze the net effect of changes in planting density, the effects of all factors except planting density must be removed. Zhu (1995) proposed a conditional variable method to exclude the background from the covariance of related traits, allowing the net effects of some factors to be identified. This method has been used to estimate the net effects of various developmental stages (Xue et al., 2019) and correlated traits (Li et al., 2020). Here, we estimated the responses of protein and oil content to planting density using this method. We performed QTL mapping for the effect of increased planting density from $2.15 \times 10^{5}$ plants/ha (D1) to $3 \times 10^{5}$ plants/ha (D2) on protein and oil content. Using linkage analysis, we identified 20 and 18 RD QTLs controlling the responses of soybean protein and oil content to density, respectively, indicating that a specific molecular mechanism regulates the response to increasing planting density from D1 to D2. Therefore, when high-quality soybean varieties suitable for high-density planting were bred, alleles with positive effects should be pyramided. Conversely, when high-quality soybean varieties suitable for lowdensity planting was selected, alleles with negative effects should be combined.

\section{Potential Candidate Genes Associated With Protein and Oil Contents}

Based on the QTLs detected under different planting densities and the responses to density difference, as well as their pathway annotations, we identified four genes that might be related to differences in protein and oil contents under different plant densities (Table 6; see bold text).

Energy produced in plants via photosynthesis is stored in the form of proteins, lipids, and other organic compounds. Glyma.10G215400.1 encodes pyruvate dehydrogenase E2 component, is mainly involved in carbon metabolism, citrate cycle (TCA cycle), and glycolysis/gluconeogenesis. This enzyme catalyzes the formation of pyruvate, which is the main substrate for the Calvin cycle, so we believe that the gene is affected by planting density, and closely related to protein and oil content. Glyma.19G190100.1 encodes an enzyme that regulates the formation of pyruvate kinase (PK) and plays an important role in carbon dioxide fixation and glycolysis in chloroplasts under light stimulation (Grodzinski et al., 1999). The enzyme participates in the glycolysis pathway, and metabolites can provide a premise 

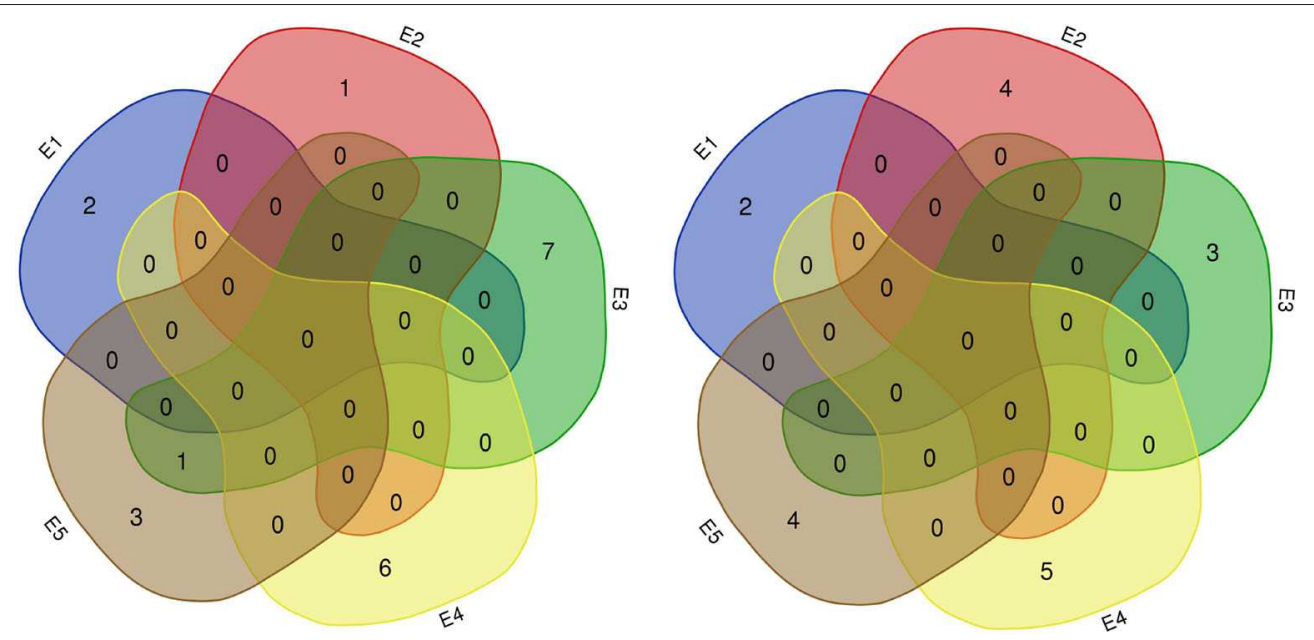

FIGURE 9 | Number of RD QTLs for protein (left) and oil (right) content detected in five environments. E1: Harbin (2015), E2: Keshan (2015), E3: Acheng (2016), E4: Shuangcheng (2016), E5: Harbin (2016).

for acetyl-CoA to form fatty acids and provide a carbon skeleton for fatty acid synthesis (Ambasht and Kayastha, 2002; Sébastien et al., 2007). Sucrose and starch produced by the glycolysis pathway can promote mitochondrial respiration and the TCA cycle, The TCA cycle is a key metabolic pathway for the oxidation of sugars, fats, and proteins (Robinson et al., 1991; Horchani et al., 2010). Therefore, we believe that this enzyme affects the protein and oil contents of soybean. Glyma.03G014600.1 encodes malate dehydrogenase (MDH), an important enzyme that catalyzes malic acid formation and is significantly affected by light stimulation, it is photo regulatory enzyme ( $\mathrm{Li}$ et al., 1999). Malate is an important intermediate metabolite in plant cells, which are many biological functions in metabolic pathways (glyoxylate cycle, tricarboxylic acid cycle, glucose synthesis, amino acid synthesis, and redox stability), we know that these metabolic pathways are related to protein and oil synthesis (Minarik et al., 2002; Matsuda et al., 2010). Moreover, this enzyme is a key enzyme in the C4 pathway in Wheat (Hata and Matsuoka, 1987) and Soybean (Hao et al., 1991), which maintain a high photosynthetic carbon assimilation capacity when the light capacity and carbon dioxide content decrease. The activity of this enzyme is affected by oxygen concentration. Changes in planting density affect the oxygen concentration around plants, and changes in the expression of Glyma.03G014600.1 affect photosynthesis and the synthesis of proteins and oils. Therefore, changes in planting density cause competition between plants, which affect the ability of plants to absorb light, as well as oxygen. Therefore, we conclude that the gene responsible for this enzyme plays a role in regulating protein and oil contents in soybean. Glyma.19G190900.1 encodes an enzyme that catalyzes the enolase, which is involved in the changes in protein and oil content resulting from change of temperature. The activity of enolase continues to increase after temperature change, which strengthen the glycolysis process, thus promoting plant growth (Thomashow, 1999). Changes in planting density result in temperature in different plant varieties. Increasing the activity of enzymes that promote the glycolysis pathway process will enhance the protein and oil contents of plants. These findings could be used to enhance the protein and oil contents of soybean in the future.

\section{Comparison of QTL Mapping Using LOD Value Is $\mathbf{3}$ and Permutation Method}

LOD (log of odd) threshold is usually used to assure the existence of QTL. There are two methods to choose LOD threshold according to research goal for detect QTL. The first method is by permutation tests (Doerge and Churchill, 1996) which will generate a higher LOD threshold to decrease false positive QTL in each detection procedure. By this method a small amount of major effect QTL could be detected (Panthee et al., 2005; Bachlava et al., 2009; Tucker et al., 2010). The shortage of this method is consumption of time in the larger amount of calculation, and even failure in a large genome data. Sun et al. (2013) propose a method to certain the LOD threshold in QTL mapping, based on the genome-wide significance level, the population type, marker density and genome size, and Zhang P. et al. (2017) specified the threshold LOD value 3.766 for ICIM and IM of four-way cross recombinant inbred lines population to control the genome-wide typed one error at an equal level of 0.05 . The second way is to set a lower LOD threshold ( $\mathrm{LOD}=2.0$, equivalently $P=0.002$ and significant at $P<0.01$ ) with objective to avoid missing of QTLs due to slightly lower significance and the putative QTL were assured by repeated detected in multiple environments or multiple genetic background (Cornelious et al., 2005; Yesudas et al., 2013; Wang et al., 2014a,b). In this research, we firstly detected QTL depending on LOD threshold generated by permutation (1,000 repeats and 0.05 type one error probability), and 5, 6, 5 QTLs for PC, OC, RDPC with higher PVE (7.19\%-38.02\%) were detected. Among the 16 QTLs, only qOC-1-1 was repeatedly identified in E1 and E2.The major QTL could be detected directly by permutation which will miss minor QTL. The detection of minor QTL is necessary 


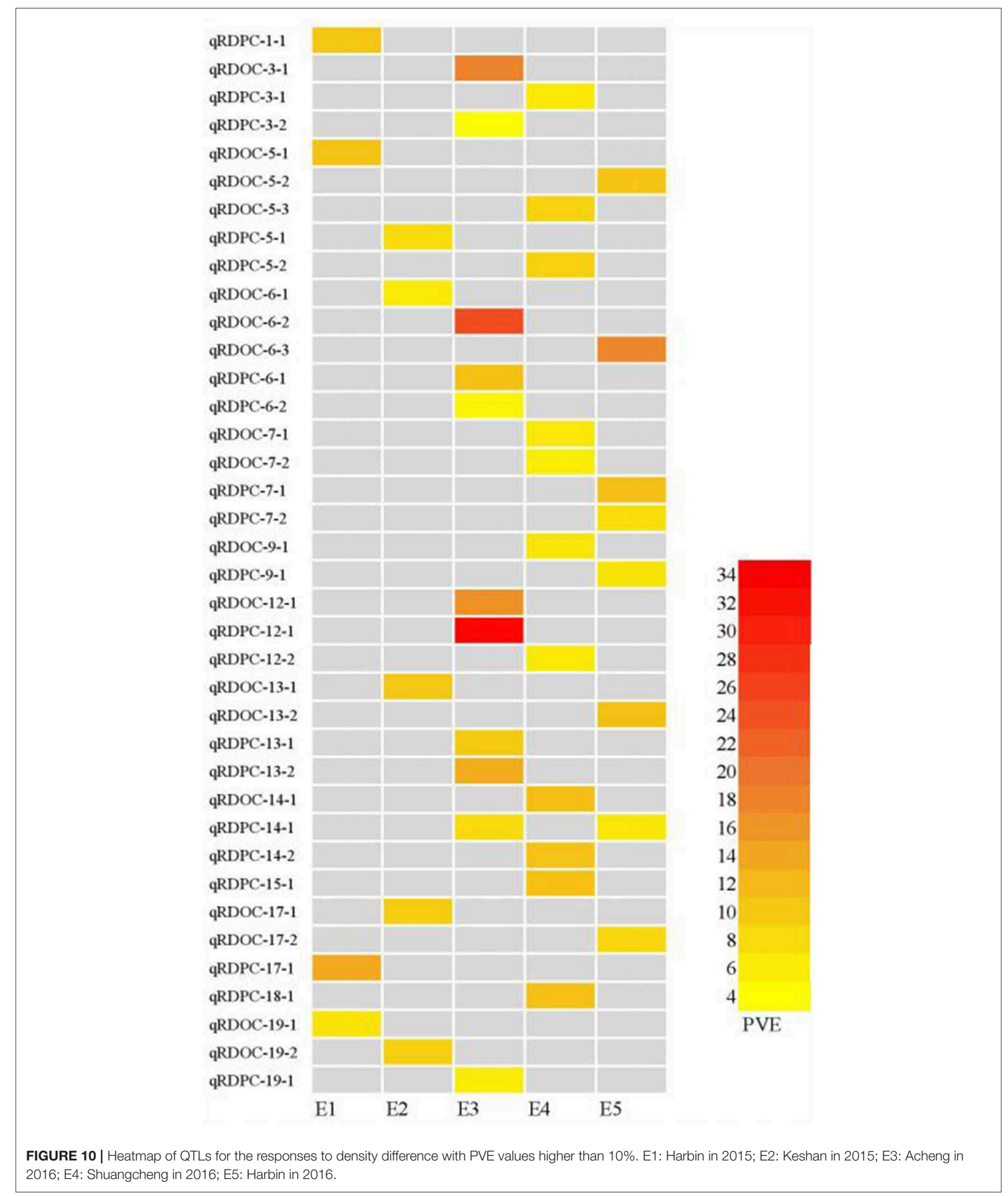

the inheritance and breeding of quality traits under multiple environments. The comparison on minor QTL detected under multiple environments and plant densities could explain the difference of genetic basis (molecular ecotypes). Furthermore, the accumulation of minor QTL could increase prediction of protein and oil content under some single planting density. Aimed 
A

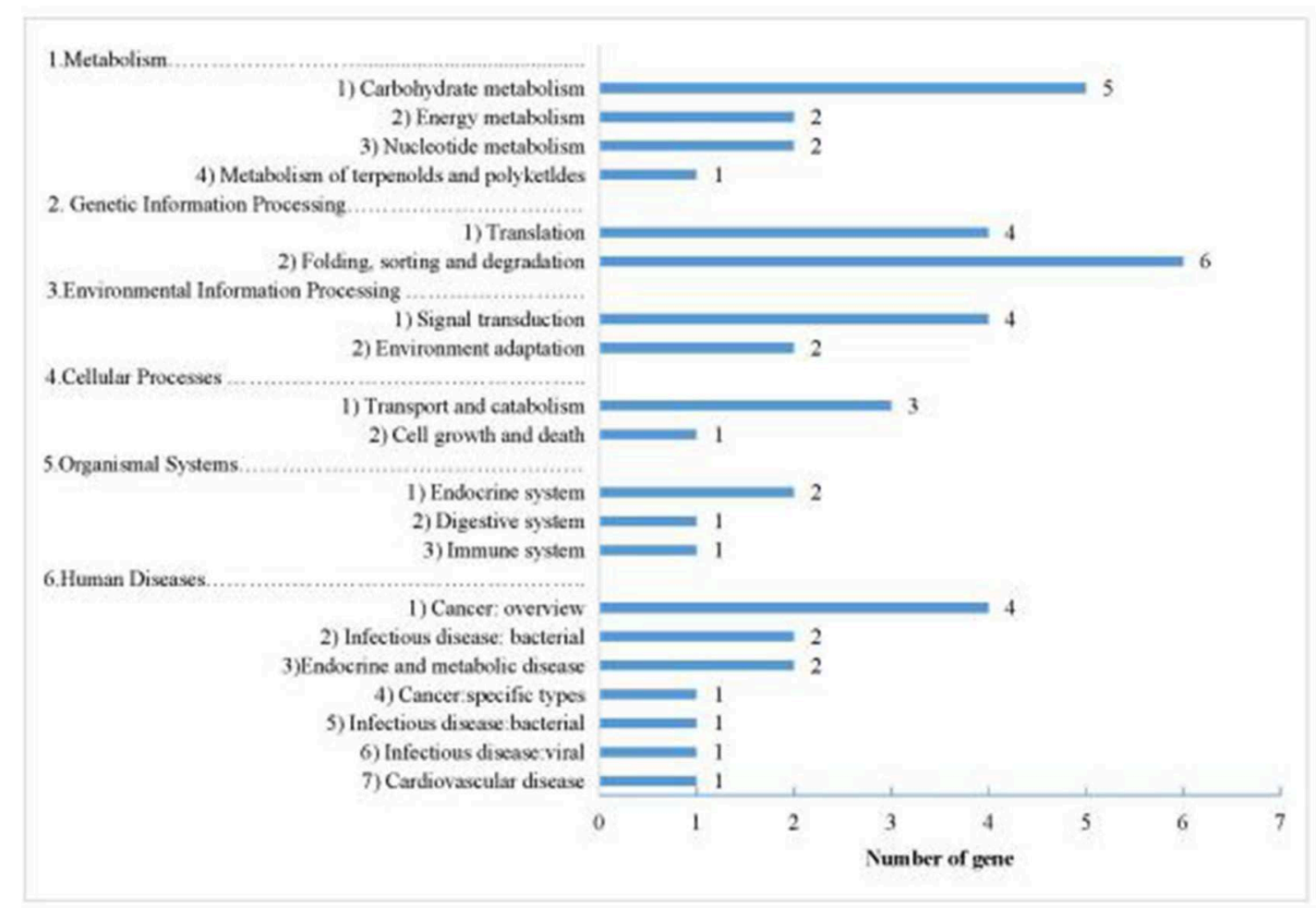

B
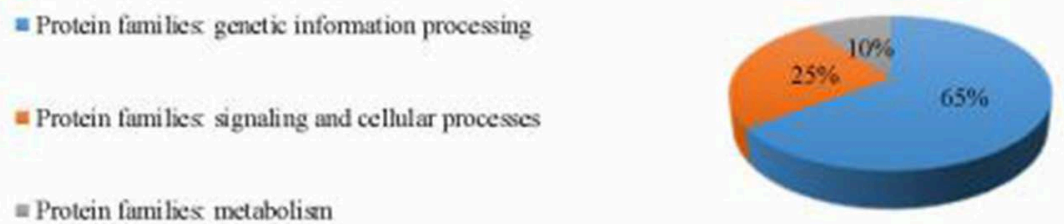

FIGURE 11 | Information about the pathways and orthologous protein families of the 26 annotated candidate genes. (A) shows information about the pathways. (B) shows information about the orthologous protein families.

to screen common and specific QTL under various densities, considering our linkage map characters (there are 1,031 marker intervals in 20 chromosome of $3539.66 \mathrm{cM}$ length) (Table S3), we choose a lower LOD threshold 3 (equivalently genome-wise $P=0.005)$ to screen QTL in the whole genome by ICIM. A total of 23, 31, 15 and 18 QTLs controlling PC, OC, RDPC, and RDOC with lower PVE (3.64-24.68\%) were added. Then, five (qOC-1-1, qOC-5-1, qOC-10-1, qPC-18-2, and qRDPC-141) and two (qOC-15-1 and qOC-7-3) of all 103 QTLs were detected repeatedly in in two environment and two planting densities, respectively. Comparing two kinds of LOD threshold, five QTLs (qOC-10-1, qOC-15-1, qOC-5-1, qOC-7-3, qRDPC14-1) could be verified the facticity by repeated identification under lower LOD threshold. In summarization, the permutation is suitable to detect the major QTL for higher PVE, and the repeated identification in multiple environments under lower threshold is feasible to discover QTL with low PVE.

\section{Comparison of the Present Study With Previous Research}

In present study, we identified 65 QTLs for protein and oil content under different planting densities and 38 QTLs 
TABLE 7 | Details about the 26 genes annotated for protein and oil content in the KEGG database.

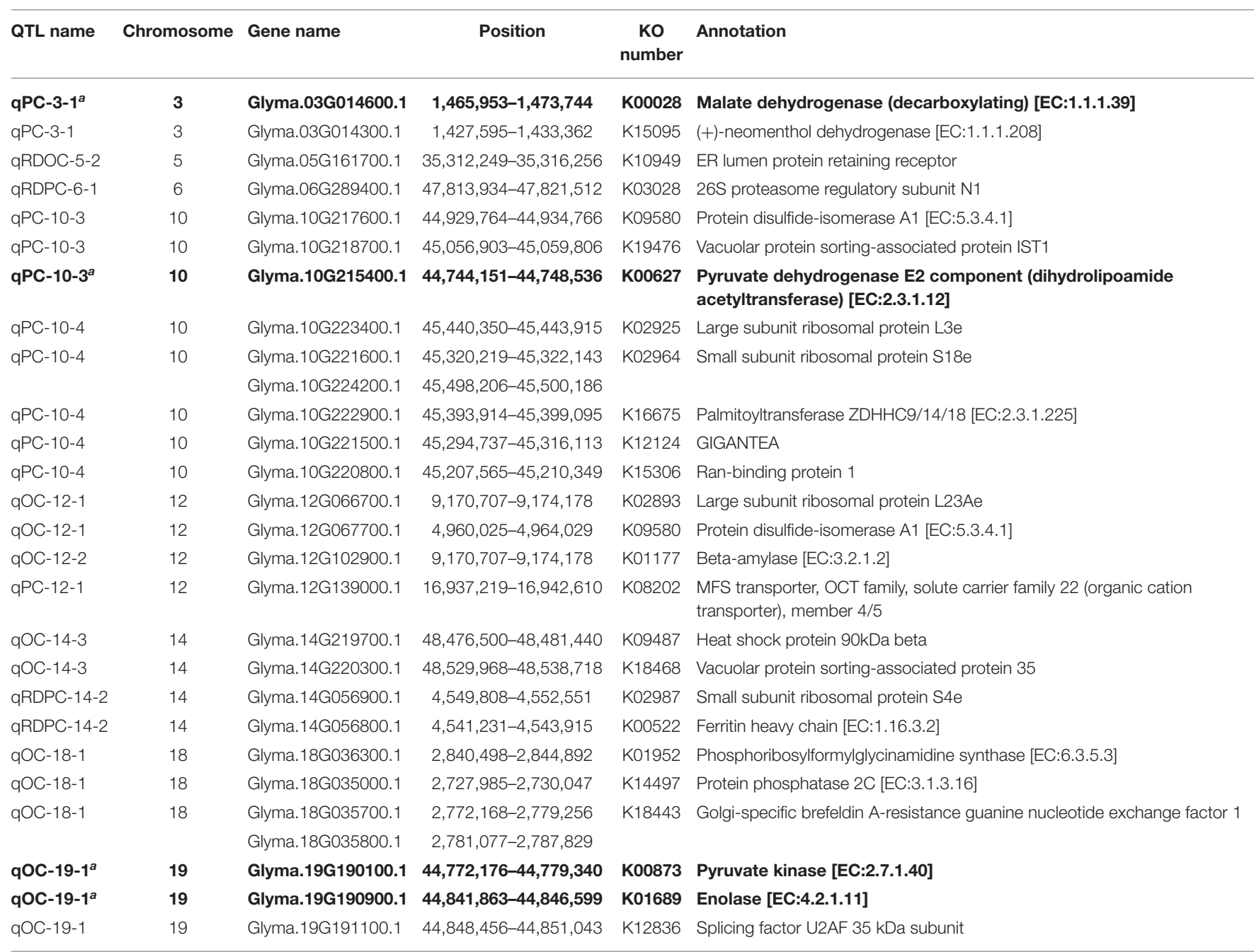

${ }^{a}$ Bold font indicates the genes relating with the protein and oil anabolism in soybean according to our deduction.

with the responses to density difference. Using the SoyBase database (http://www.soybase.org/), we concluded that 70 QTLs were in agreement with previous reports, including 29 QTLs that overlapped with marker intervals identified in previous studies (Lark et al., 1994; Mansur et al., 1996; Brummer et al., 1997; Chapman et al., 2003; Tajuddin et al., 2003; Hyten et al., 2004; Stombaugh et al., 2004; Reinprecht et al., 2006; Chen et al., 2007; Gai et al., 2007; Liang et al., 2010; Qi et al., 2011b; Lu et al., 2013; Mao et al., 2013; Pathan et al., 2013; Rossi et al., 2013; Akond et al., 2014; Wang et al., 2014b; Han et al., 2015; Warrington et al., 2015). More importantly, the PVE for 29 QTLs was $>10 \%$. The significance of these regions was used to identify genes responsible for the increased protein and oil contents of soybean under increased planting density.

The remaining QTLs that are consistent with previously reported QTLs for protein and oil content are listed in Tables 3-5. Among the QTLs detected, 33 novel QTLs (qPC-1-1, qPC-5-2, qPC-10-4, qPC-3-1, qPC-5-1, qPC-8-2,
qPC-12-1, qPC-12-2, qPC-14-1, qOC-7-1, qOC-10-1, qOC12-2, qOC-18-2, qOC-19-2, qOC-8-2, qOC-9-2, qOC-13-2, qOC-18-1, qRDPC-1-1, qRDPC-3-1, qRDPC-3-2, qRDPC-6-2, qRDPC-7-2, qRDPC-12-1, qRDPC-15-1, qRDPC-19-1, qRDOC5-2, qRDOC-5-3, qRDOC-6-1, qRDOC-6-2, qRDOC-13-1, qRDOC-13-2, qRDOC-19-1) were identified. These QTLs require further verification before they can be used in breeding programs.

\section{SUMMARY}

In this study, we identified 65 QTLs for protein and oil content under different planting densities and 38 QTLs with density responses based on SNP mapping. Based on these QTLs, four candidate genes were identified: these genes are affected by planting density and control protein and oil content. The molecular mechanism for the formation of protein and oil content under multiple planting densities involves the cumulative effects of QTLs 
and the response to increases in planting density. These findings lay the foundation for enhancing protein and oil contents and increasing yields in soybean at specific planting densities.

\section{DATA AVAILABILITY STATEMENT}

The datasets GENERATED for this study can be found in Figshare: https://figshare.com/s/4a7b8caea2c29f891bc3.

\section{AUTHOR CONTRIBUTIONS}

$\mathrm{W}-\mathrm{XL}$ and HN conceived and designed the experiments. XS, XL, JS, ZQ, YW, YF, JW, SJ, and CY performed the field experiments and quality analysis. SL and ZT performed the genotyping. KZ, XT, and $\mathrm{HN}$ analyzed data, drafted and revised the manuscript.

\section{REFERENCES}

Akond, A. M., Ragin, B., Bazzelle, R., Kantartzi, S. K., Meksem, K., and Kassem, M. A. (2012). Quantitative trait loci associated with moisture, protein, and oil content in soybean [Glycine max (L.) Merr.]. J Agr Sci. 4:16. doi: 10.5539/jas.v4n11p16

Akond, M., Liu, S., Boney, M., Kantartzi, S. K., Meksem, K., Bellaloui, N., et al. (2014). Identification of quantitative trait loci (QTL) underlying protein, oil, and five major fatty acids' contents in soybean. AJPS 5:158. doi: 10.4236/ajps.2014.51021

Ambasht, P. K., and Kayastha, A. M. (2002). Plant pyruvate kinase. Biol. Plantarum 45, 1-10. doi: 10.1023/A:1015173724712

Asekova, S., Kulkarni, K. P., Kim, M., Kim, J. H., Song, J. T., Shannon, J. G., et al. (2016). Novel quantitative trait loci for forage quality traits in a cross between PI 483463 and 'Hutcheson'in soybean. Crop Sci. 56, 2600-2611. doi: 10.2135/cropsci2016.02.0125

Bachlava, E., Dewey, R. E., Burton, J. W., and Cardinal, A. J. (2009). Mapping and comparison of quantitative trait loci for oleic acid seed content in two segregating soybean populations. Crop Sci. 49, 433-442. doi: 10.2135/cropsci2008.06.0324

Belamkar, V., Farmer, A. D., Weeks, N. T., Kalberer, S. R., Blackmon, W. J., and Cannon, S. B. (2016). Genomics-assisted characterization of a breeding collection of Apios americana, an edible tuberous legume. Sci. Rep. 6:34908. doi: 10.1038/srep34908

Bellaloui, N., Mengistu, A., Walker, E. R., and Young, L. D. (2014). Soybean seed composition as affected by seeding rates and row spacing. Crop Sci. 54, 1782-1795. doi: 10.2135/cropsci2013.07.0463

Brummer, E., Graef, G., Orf, J., Wilcox, J., and Shoemaker, R. (1997). Mapping QTL for seed protein and oil content in eight soybean populations. Crop Sci. 37, 370-378. doi: 10.2135/cropsci1997.0011183X0037000 20011x

Chapman, A., Pantalone, V., Ustun, A., Allen, F., Landau-Ellis, D., Trigiano, R., et al. (2003). Quantitative trait loci for agronomic and seed quality traits in an $\mathrm{F}_{2}$ and $\mathrm{F}_{4: 6}$ soybean population. Euphytica 129, 387-393. doi: 10.1023/A:1022282726117

Chen, Q. S., Zhang, Z. C., Liu, C. Y., Xin, D. W., Qiu, H. M., Shan, D. P., et al. (2007). QTL analysis of major agronomic traits in soybean. Agr. Sci. Chin. 6, 399-405. doi: 10.1016/S1671-2927(07)60062-5

Cornelious, B., Chen, P., Chen, Y., Leon, N., Shannon, J. G., and Wang, D. (2005). Identification of QTLs underlying water-logging

\section{FUNDING}

This study was funded by a grant from the National Key Research and Development Program of China (2017YFD0101303 to W-XL).

\section{SUPPLEMENTARY MATERIAL}

The Supplementary Material for this article can be found online at: https://www.frontiersin.org/articles/10.3389/fgene. 2020.00563/full\#supplementary-material

Table S1 | Comparison of parental source and quality traits.

Table S2 | Planting conditions of the parents and FW-RIL population used for field experiments in five environments.

Table S3 | Description of characteristics of 20 chromosomes in the high-density genetic map.

Figure S1 | Frequency of positive alleles of QTLs related to protein (left) and oil (right) contents based on their distribution in each parent under different planting densities and in response to density.

tolerance in soybean. Mol. Breed. 16, 103-112. doi: 10.1007/s11032-0055911-2

Csanádi, G., Vollmann, J., Stift, G., and Lelley, T. (2001). Seed quality QTLs identified in a molecular map of early maturing soybean. Theor. Appl. Genet. 103, 912-919. doi: 10.1007/s001220100621

Diers, B. W., Keim, P., Fehr, W., and Shoemaker, R. (1992). RFLP analysis of soybean seed protein and oil content. Theor. Appl. Genet. 83, 608-612. doi: 10.1007/BF00226905

Doerge, R. W., and Churchill, G. A. (1996). Permutation tests for multiple loci affecting a quantitative Character. Genetics 142, 285-294.

Doyle, J. J., and Doyle, J. L. (1990). Isolation ofplant DNA from fresh tissue. Focus 12, 39-40.

Eskandari, M., Cober, E. R., and Rajcan, I. (2013). Genetic control of soybean seed oil: II. QTL and genes that increase oil concentration without decreasing protein or with increased seed yield. Theor. Appl. Genet. 126, 1677-1687. doi: 10.1007/s00122-013-2083-z

Gai, J., Wang, Y., Wu, X., and Chen, S. (2007). A comparative study on segregation analysis and QTL mapping of quantitative traits in plants-with a case in soybean. Front. Agric. Chin. 1, 1-7. doi: 10.1007/s11703-007-0001-3

Grodzinski, B., Jiao, J., and Plaxton, K. W. C. (1999). Photosynthesis and carbon partitioning in transgenic tobacco plants deficient in leaf cytosolic pyruvate kinase. Plant Physiol. 120, 887-895. doi: 10.1104/pp.120.3.887

Han, Y., Teng, W., Wang, Y., Zhao, X., Wu, L., Li, D., et al. (2015). Unconditional and conditional QTL underlying the genetic interrelationships between soybean seed isoflavone, and protein or oil contents. Plant Breed. 134, 300-309. doi: $10.1111 /$ pbr.12259

Hao, N. B., Tan, K. H., Na, Q. S., Jia, Z. W., Ge, Q. Y., and Zhang, Y. Z. (1991). A comparative study of PEPC activity of green or gansin C3 plant. Acta BotSin. 33, 692-697.

Hata, S., and Matsuoka, M. (1987). Immunological studies on pyruvate orthophosphate dikinase in C3 plants. Plant Cell Physiol. 28, 635-641.

Horchani, F., Hajri, R., and Aschi-Smiti, S. (2010). Effect of ammonium or nitrate nutrition on photosynthesis, growth, and nitrogen assimilation in tomato plants. J. Plant Nutr. Soil Sci. 173, 610-617. doi: 10.1002/jpln.201000055

Hyten, D., Pantalone, V., Sams, C., Saxton, A., Landau-Ellis, D., Stefaniak, T., et al. (2004). Seed quality QTL in a prominent soybean population. Theor. Appl. Genet. 109, 552-561. doi: 10.1007/s00122-004-1661-5

Jun, T. H., Van, K., Kim, M. Y., Lee, S. H., and Walker, D. R. (2008). Association analysis using SSR markers to find QTL for seed protein content in soybean. Euphytica 162, 179-191. doi: 10.1007/s10681-007-9491-6 
Ku, L., Zhang, L., Tian, Z., Guo, S., Su, H., Ren, Z., et al. (2015). Dissection of the genetic architecture underlying the plant density response by mapping plant height-related traits in maize (Zea mays L.). Mol. Genet. Genomics 290, 1223-1233. doi: 10.1007/s00438-014-0987-1

Lark, K., Orf, J., and Mansur, L. (1994). Epistatic expression of quantitative trait loci (QTL) in soybean [Glycine max (L.) Merr.] determined by QTL association with RFLP alleles. Theor. Appl. Genet. 88, 486-489. doi: 10.1007/BF00223665

Lee, S., Jun, T., Michel, A. P., and Mian, M. R. (2015). SNP markers linked to QTL conditioning plant height, lodging, and maturity in soybean. Euphytica 203, 521-532. doi: 10.1007/s10681-014-1252-8

Lee, S. H., Bailey, M. A., Mian, M. A. R., Carter, T. E., Shipe, E. R., Ashley, D. A., et al. (1996). RFLP loci associated with soybean seed protein and oil content across populations and locations. Theor. Appl. Genet. 93, 649-657. doi: $10.1007 /$ bf 00224058

Leite, D., Pinheiro, J. B., Campos, J., Di Mauro, A., and Unêda-Trevisoli, S. (2016). QTL mapping of soybean oil content for marker-assisted selection in plant breeding program. Genet. Mol. Res. 15:11. doi: 10.4238/gmr.15017685

Li, H., Zhao, T., Wang, Y., Yu, D., Chen, S., Zhou, R., et al. (2011). Genetic structure composed of additive QTL, epistatic QTL pairs and collective unmapped minor QTL conferring oil content and fatty acid components of soybeans. Euphytica 182:117. doi: 10.1007/s10681-011-0524-9

Li, W. H., Hao, N. B., Ge, Q. Y., and Zhang, Q. D. (1999). Advances in study on C4 path way in C3 plant. Chin. Bull. Bot. 16, 97-106.

Li, X., Xue, H., Zhang, K., Li, W., Fang, Y., Qi, Z., et al. (2020). Mapping QTLs for protein and oil content in soybean by removing the influence of related traits in a four-way recombinant inbred line population. J. Agr. Sci. 157, 659-675. doi: $10.1017 /$ S0021859620000040

Liang, H. Z., Yu, Y. L., Wang, S. F., Yun, L., Wang, T. F., Wei, Y. L., et al. (2010). QTL mapping of isoflavone, oil and protein contents in soybean (Glycine max [L] Merri.). Agr. Sci. Chin. 9, 1108-1116. doi: 10.1016/S1671-2927(09)60197-8

Liu, N., Li, M., Hu, X., Ma, Q., Mu, Y., Tan, Z., et al. (2017). Construction of high-density genetic map and QTL mapping of yield-related and two quality traits in soybean RILs population by RAD-sequencing. BMC Genomics 18:466. doi: 10.1186/s12864-017-3854-8

Liu, S., Xue, H., Zhang, K., Wang, P., Su, D., Li, W., et al. (2019). Mapping QTL affecting the vertical distribution and seed set of soybean [Glycine max (L.) Merr.] pods. Crop J.7, 694-706. doi: 10.1016/j.cj.2019.04.004

Lu, W., Wen, Z., Li, H., Yuan, D., Li, J., Zhang, H., et al. (2013). Identification of the quantitative trait loci (QTL) underlying water soluble protein content in soybean. Theor. Appl. Genet. 126, 425-433. doi: 10.1007/s00122-012-1990-8

Mansur, L., Orf, J. H., Chase, K., Jarvik, T., Cregan, P., and Lark, K. (1996). Genetic mapping of agronomic traits using recombinant inbred lines of soybean. Crop Sci. 36, 1327-1336. doi: 10.2135/cropsci1996.0011183X003600050042x

Mao, T., Jiang, Z., Han, Y., Teng, W., Zhao, X., and Li, W. (2013). Identification of quantitative trait loci underlying seed protein and oil contents of soybean across multi - genetic backgrounds and environments. Plant Breed. 132, 630-641. doi: 10.1111/pbr.12091

Matsuda, T., Takahashi-Yanaga, F., Yoshihara, T., Maenaka, K., Watanabe, Y., Miwa, Y., et al. (2010). Dictyostelium differentiation-inducing factor-1 binds to mitochondrial malate dehydrogenase and inhibits its activity. J. Pharmacol. Sci. 112, 320-326. doi: 10.1254/jphs.09348FP

Minarik, P., Tomaskova, K., Kollarova, M., and Anlalik, M. (2002). Malale dehydrogenases stracture and function. Gen. Physiol. Biophys. 21, 257-265. doi: 10.2478/acb-2014-0005

Ning, H., Bai, X. L., Li, W. B., Xue, H., Zhang, X., Li, W. X., et al. (2016). Mapping QTL protein and oil contents using population from four-way recombinant inbred lines for soybean (Glycine max L. Merr). Acta Agron. Sin. 42, 1620-1628.

Orf, J. H., Chase, K., Jarvik, T., Mansur, L., Cregan, P., Adler, F., et al. (1999). Genetics of soybean agronomic traits: I. comparison of three related recombinant inbred populations. Crop Sci. 39, 1642-1651. doi: $10.2135 /$ cropsci1999.3961642x

Osman, K. A., Tang, B., Wang, Y., Chen, J., Yu, F., Li, L., et al. (2013). Dynamic QTL analysis and candidate gene mapping for waterlogging tolerance at maize seedling stage. PLoS ONE 8:e79305. doi: 10.1371/journal.pone.0079305

Panthee, D. R., Pantalone, V. R., West, D. R., Saxton, A. M., and Sams, C. E. (2005). Quantitative trait loci for seed protein and oil concentration, and seed size in soybean. Crop Sci. 45, 2015-2022. doi: 10.2135/cropsci2004.0720
Pathan, S. M., Vuong, T., Clark, K., Lee, J. D., Shannon, J. G., Roberts, C. A., et al. (2013). Genetic mapping and confirmation of quantitative trait loci for seed protein and oil contents and seed weight in soybean. Crop Sci. 53, 765-774. doi: 10.2135/cropsci2012.03.0153

Powell, W., Morgante, M., Andre, C., Hanafey, M., Vogel, J., Tingey, S., et al. (1996). The comparison of RFLP, RAPD, AFLP and SSR (microsatellite) markers for germplasm analysis. Mol. Breed. 2, 225-238. doi: $10.1007 / \mathrm{BF} 00564200$

Qi, Z., Hou, M., Han, X., Liu, C., Jiang, H., Xin, D., et al. (2014). Identification of quantitative trait loci (QTL s) for seed protein concentration in soybean and analysis for additive effects and epistatic effects of QTL $s$ under multiple environments. Plant Breed. 133, 499-507. doi: 10.1111/pbr.12179

Qi, Z. M., Wu, Q., Han, X., Sun, Y. N., Du, X. Y., Liu, C. Y., et al. (2011a). Soybean oil content QTL mapping and integrating with meta-analysis method for mining genes. Euphytica 179, 499-514. doi: 10.1007/s10681-011-0386-1

Qi, Z. M., Xue, H., Sun, Y. N., Qiong, W., Shan, D. P., Du, X. Y., et al. (2011b). An integrated quantitative trait locus map of oil content in soybean, Glycine max (L.) Merr., generated using a meta-analysis method for mining genes. Agr. Sci. Chin. 10, 1681-1692. doi: 10.1016/S1671-2927(11)60166-1

Rajcan, I., Hou, G., and Weir, A. D. (2005). Advances in breeding of seed-quality traits in soybean. J. Crop Improve. 14, 145-174. doi: 10.1300/J411v14n01_07

Reinprecht, Y., Poysa, V. W., Yu, K., Rajcan, I., Ablett, G. R., and Pauls, K. P. (2006). Seed and agronomic QTL in low linolenic acid, lipoxygenasefree soybean (Glycine max (L.) Merrill) germplasm. Genome 49, 1510-1527. doi: $10.1139 / \mathrm{g} 06-112$

Robinson, S. A., Slade, A. P., Fox, G. G., Phillips, R., and Stewart, R. G. R. (1991). The role of glutamate dehydrogenase in plant nitrogen metabolism. Plant Physiol. 95, 509-516. doi: 10.1104/pp.95.2.509

Rossi, M. E., Orf, J. H., Liu, L. J., Dong, Z., and Rajcan, I. (2013). Genetic basis of soybean adaptation to North American vs. Asian mega-environments in two independent populations from Canadian $\times$ Chinese crosses. Theor. Appl. Genet. 126, 1809-1823. doi: 10.1007/s00122-013-2094-9

Sébastien, B., Sylvie, W., Dubreucq, B., Aurélie, D. A., and Rochat, C. (2007). Function of plastidial pyruvate kinase in seeds of Arabidopsis thaliana. Plant J. 52, 405-419. doi: 10.1111/j.1365-313X.2007.03232.x

Specht, J. E., Chase, K., Macrander, M., Graef, G. L., Chung, J., and arkwell, J. P., et al. (2001). Soybean response to water: a QTL analysis of drought tolerance. Crop Sci. 41, 493-509. doi: 10.2135/cropsci2001.412493x

Stombaugh, S., Orf, J. H., Jung, H., Chase, K., Lark, K., and Somers, D. (2004). Quantitative trait loci associated with cell wall polysaccharides in soybean seed. Crop Sci. 44, 2101-2106. doi: 10.2135/cropsci2004.2101

Sun, Z., Li, H., Zhang, L., and Wang, J. (2013). Properties of the test statistic under null hypothesis and the calculation of LOD threshold in quantitative trait loci (QTL) mapping. Acta Agron. Sin. 39, 1-11. doi: 10.3724/SP.J.1006.2013.00001

Tajuddin, T., Watanabe, S., Yamanaka, N., and Harada, K. (2003). Analysis of quantitative trait loci for protein and lipid contents in soybean seeds using recombinant inbred lines. Breed. Sci. 53, 133-140. doi: 10.1270/jsbbs.53.133

Thomashow, M. F. (1999). Plant cold acclimation: freezing tolerance genes and regulatory mechanisms. Annu. Rev. Plant Biol. 50, 571-599. doi: 10.1146/annurev.arplant.50.1.571

Tucker, D. M., Saghai-Maroof, M. A., Mideros, S., Skoneczka, J. A., Nabati, D. A., Buss, G. R., et al. (2010). Mapping quantitative trait loci for partial resistance to Phytophthora sojae in a soybean interspecific cross. Crop Sci. 50, 628-635. doi: 10.2135/cropsci2009.03.0161

Wang, J., Chen, P., Wang, D., Shannon, G., Zeng, A., Orazaly, M., et al. (2015). Identification and mapping of stable QTL for protein content in soybean seeds. Mol. Breed. 35:92. doi: 10.1007/s11032-015-0285-6

Wang, X., Jiang, G. L., Green, M., Scott, R. A., Hyten, D. L., et al. (2014a). Quantitative trait locus analysis of unsaturated fatty acids in a recombinant inbred population of soybean. Mol. Breed. 33, 281-296. doi: $10.1007 / \mathrm{s} 11032-013-9948-3$

Wang, X., Jiang, G. L., Green, M., Scott, R. A., Song, Q., Hyten, D. L., et al. (2014b). Identification and validation of quantitative trait loci for seed yield, oil and protein contents in two recombinant inbred line populations of soybean. Mol. Genet. Genomics 289, 935-949. doi: 10.1007/s00438-014-0865-x

Warrington, C., Abdel-Haleem, H., Hyten, D., Cregan, P., Orf, J., Killam, A., et al. (2015). QTL for seed protein and amino acids in the Benning $\times$ 
Danbaekkong soybean population. Theor. Appl. Genet. 128, 839-850. doi: 10.1007/s00122-015-2474-4

Xue, H., Tian, X., Zhang, K., Li, W., Qi, Z., Fang, Y., et al. (2019). Mapping developmental QTL for plant height in soybean [Glycine $\max$ (L.) Merr.] using a four-way recombinant inbred line population. PLOS ONE 14:e0224897. doi: 10.1371/journal.pone.02 24897

Yesudas, C. R., Bashir, R., Geisler, M. B., and Lightfoot, D. A. (2013). Identification of germplasm with stacked QTL underlying seed traits in an inbred soybean population from cultivars Essex and Forrest. Mol. Breed. 31, 693-703. doi: 10.1007/s11032-012-9827-3

Zhang, K., Liu, S., Li, W., Liu, S., Li, X., Fang, Y., et al. (2018). Identification of QTNs controlling seed protein content in soybean using multi-locus genome-wide association studies. Front. Plant Sci. 9:1690. doi: 10.3389/fpls.2018.01690

Zhang, P., Yin, G., Zhou, Y., Qi, A., Gao, F., Xia, X., et al. (2017). QTL mapping of adult-plant resistance to leaf rust in the wheat cross Zhou 8425B/Chinese spring using high-density SNP markers. Front. Plant Sci. 8:793. doi: 10.3389/fpls.2017. 00793
Zhang, S., Meng, L., Wang, J., and Zhang, L. (2017). Background controlled QTL mapping in pure-line genetic populations derived from four-way crosses. Heredity 119, 256-264. doi: 10.1038/hdy.2017.42

$\mathrm{Zhu}, \mathrm{J}$. (1995). Analysis of conditional genetic effects and variance components in developmental genetics. Genetics 141, 1633-1639. doi: 10.1002/gcc.2870140411

Conflict of Interest: The authors declare that the research was conducted in the absence of any commercial or financial relationships that could be construed as a potential conflict of interest.

Copyright (c) 2020 Tian, Zhang, Liu, Sun, Li, Song, Qi, Wang, Fang, Wang, Jiang, Yang, Tian, Li and Ning. This is an open-access article distributed under the terms of the Creative Commons Attribution License (CC BY). The use, distribution or reproduction in other forums is permitted, provided the original author(s) and the copyright owner(s) are credited and that the original publication in this journal is cited, in accordance with accepted academic practice. No use, distribution or reproduction is permitted which does not comply with these terms. 